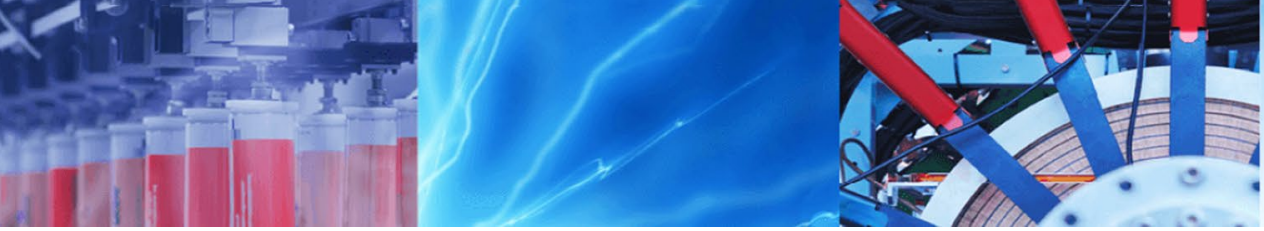

Review Paper

\title{
Perspectives on the antibiotic contamination, resistance, metabolomics, and systemic remediation
}

\author{
Kushneet Kaur Sodhi ${ }^{1} \cdot$ Mohit Kumarr $^{1,2} \cdot$ Biji Balan $^{1} \cdot$ Amit Singh Dhaulaniya ${ }^{1} \cdot$ Pallee Shree $^{3} \cdot$ Nitika Sharma $^{1}$. \\ Dileep Kumar Singh ${ }^{1}$ (i)
}

Received: 29 August 2020 / Accepted: 21 December 2020 / Published online: 3 February 2021

(C) The Author(s) 2021 OPEN

\begin{abstract}
Antibiotics have been regarded as the emerging contaminants because of their massive use in humans and veterinary medicines and their persistence in the environment. The global concern of antibiotic contamination to different environmental matrices and the emergence of antibiotic resistance has posed a severe impact on the environment. Different mass-spectrometry-based techniques confirm their presence in the environment. Antibiotics are released into the environment through the wastewater steams and runoff from land application of manure. The microorganisms get exposed to the antibiotics resulting in the development of antimicrobial resistance. Consistent release of the antibiotics, even in trace amount into the soil and water ecosystem, is the major concern because the antibiotics can lead to multi-resistance in bacteria which can cause hazardous effects on agriculture, aquaculture, human, and livestock. A better understanding of the correlation between the antibiotic use and occurrence of antibiotic resistance can help in the development of policies to promote the judicious use of antibiotics. The present review puts a light on the remediation, transportation, uptake, and antibiotic resistance in the environment along with a novel approach of creating a database for systemic remediation, and metabolomics for the cleaner and safer environment.
\end{abstract}

Keywords Antibiotic contamination · Detection · Bacteria · Phytoremediation · Systems biology · Omics

\section{Introduction}

Antibiotics term first introduced in the 1940s with the clinical use of penicillin. The subsequent development of other antibiotics has proved to be effective against bacterial infections. These bacterial infections are considered to be under therapeutic control because of the effectiveness of these antibiotics. Excessive use and misuse of antibiotics have caused a significant threat to human health. Antibiotics are ubiquitous in nature whose residues has been frequently found in different environmental matrices, e.g., soil, groundwater, surface water, wastewater, sediments, and sludge [64, 65, 90, 119, 156, 157, 195, 199, 220, 223]. The effluent wastewater from industries, hospitals, aquaculture, and domestics may be a significant contributor of antibiotics to aquatic environments. The "pollution potential" of poultry manure get influenced by the specific compositions of antibiotics [214]. The antibiotic concentration varies depending on the soil's type and texture [204]. Antibiotic finds its way to the vegetation via the use of livestock waste in manure. Livestock waste containing antibiotics is used as manure to enhance the texture, fertility, and conditioning of the soil $[73,140]$. The transfer of antibiotic residues and their active metabolites from

Kushneet Kaur Sodhi and Mohit Kumar contributed equally and are first authors.

Dileep Kumar Singh, dileepksingh@gmail.com | ${ }^{1}$ Soil Microbial Ecology and Environmental Toxicology Laboratory, Department of Zoology, University of Delhi, New Delhi, Delhi 110007, India. ${ }^{2}$ Department of Zoology, Hindu College, University of Delhi, Delhi 110007, India. ${ }^{3}$ Department of Zoology, Bhaskaracharya College of Applied Sciences, University of Delhi, Delhi 110075, India. 
the slurry to the harvested vegetables has been shown from time to time $[25,73,75,77-79,112,135,140$, Doliver et al. 2007]. The soil also exerts its buffering behavior on antibiotics, antibiotic-resistant genes (ARGs), and antibiotic-resistant bacteria (ARB). This effect makes applied manure ARBs and ARGs non-effective among existing soil microbial communities due to the remediation process employed by existing microbes. However, the resistance in manured biota can also be managed by manure treatment [104]. Extensive information is available on antibiotic resistance. However, only few studies are available on antibiotic degradation, and fewer studies are available that have investigated microorganisms which use them as energy and carbon sources. Thus, the degrdataion mechanism of microorganisms is not well understood.

Due to technological advancements in the last few decades, new methods and tools are designed which has high accuracy and sensitivity to study the pharmaceutical compounds in the environmental compartments. Regardless of the immense importance of antibiotics to treat bacterial infections, they are posing a major threat to mankind. Fluoroquinolones (FQs) such as ciprofloxacin was detected in hospital effluent in the concentration of $0.7-124.5 \mu \mathrm{g} / \mathrm{L}$. Ampicillin was detected in the German hospitals in the range of $20-80 \mu \mathrm{g} / \mathrm{L}$ [114]. The hospital effluents get diluted by municipal sewage which lowers the concentration of the antibiotic moderately because the municipal wastewater also contains livestock, veterinary, and household waste. Soils are contaminated with antibiotics when manures, sludge, and wastewater are applied to land [46], but some antibiotics are directly applied to farmland for controlling the pathogens [189]. Aquatic resources receives antibiotics via waste water and aquaculture facilities [29]. The quinolones such as FQs, erythromycin, sulfonamides are frequently detected in the groundwater, surface water, and effluents of Wastewater treatment plants (WWTPs) in the $\mu \mathrm{g} / \mathrm{L}$ range. Tetracycline (TET) has been detected in the soil in $0.2 \mathrm{~g} / \mathrm{kg}$ concentration and sediments. The European Commission has admitted that "the soil and water pollutions with pharmaceuticals is a critical concern for the public health and an important environmental issue" [106]. The antibiotics which are the most commonly found in soil are triclosan, sulfadiazine, and trimethoprim. The antibiotics are found in soil at a lower concentration as compared to water resources. Trimethoprim is recorded in the highest concentration $(60 \mathrm{mg} / \mathrm{kg})$ in Malaysia [88]. The pharamaceuticals' concentration is the highest in the sewage treatment plants (STPs) as compared to surface water. The pharamceuticals get attenuated in the surface water as the natural processes such as photolysis, dispersion, sorption, biotranformation, and volatization operates in the surface water [81]. The antibiotics (sulfamethaxazole and trimethroprim) are present in high concentrations in the freshwater and STPs in Asia. In countries like China the antibiotics are present at high concentrations in the river and effluent as no prescription is needed for the sale of antibiotics which leads to the over-dosing of antibiotics [121]. According to the List of emerging pollutants "Watch List" of the European Union (EU). Some antibiotic compounds such as amoxicillin and ciprofloxacin are replaced on the EU Watch List in 2015, and azithromycin, erythromycin, and clarithromycin were added to this list in 2018 (https://ec.europa.eu/jrc/ en/science-update/updated-surface-water-watch-listadopted-commission). TET and oxytetracycline (OTC) are widely used antibiotics in veterinary applications [96]. The antibiotics poses a serious risk to animals, humans, and plants. Antibiotics causes chronic and acute toxicity to living beings along with the damage to aquatic phytoplanktons, also have an impact on indigeneous microbial populations and ARGS in microorganisms $[127,128]$.

The present review puts a light on the remediation, transportation, uptake, and antibiotic resistance in the environment along with a novel approach of creating a database for systemic remediation, and metabolomics for the cleaner and safer environment.

\section{Remediation and ecological resilience}

The degradation process involves the complete mineralization of the parent compound to a lesser toxic or unreactive compound in the environment, under the naturally existing metabolic/co-metabolic processes of microbial load. The removal efficiency of antibiotics mostly depends on the sorption potential of suspended solids through the process of sedimentation. The removal efficiencies for Trimethoprim (TMP), norfloxacin (NOR), and TC were reported as $43 \%, 52 \%$, and $69 \%$, respectively, while Ofloxacin (OFX) removal efficiency was only $12 \%$ in each treatment. The STPs are not completely efficient for antibiotic removal. For Ex. antibiotics such as sulfamethoxazole, amoxicillin, cefalexin, chloramphenicol, and cefotaxime were found with overall removal of $80 \%, 75 \%, 81 \%, 77 \%$, and $94 \%$, respectively, with up to $>70 \%$ removal of cefalexin and cefotaxime from activated sludge. The overall removal efficiencies of antibiotics can be calculated by the ratio of mass loads of influent and effluent [121]. The microorganisms are successful in degrading the antibiotics and reducing the environmental load/contamination, but the exact mechanism and pathways remain unclear [20]. However, the degradation can be accelerated using consortia. Alexandrine et al. (2017) showed up to $65 \%$ of enrofloxacin and $55 \%$ of ceftiofur degradation through microbial applications, and limits of detection (LOD) were observed as $0.1 \mathrm{mg} / \mathrm{L}$. Sulfonamides are one of the frequently used 
antibiotics (both in humans and animals) due to their higher antibacterial activity against Gram-negative, Grampositive bacteria, and protozoan diseases [117]. Liao et al. $[124,125]$ showed the successful linear biodegradation of sulfanilamide through acclimatized populations, which was about $78 \%$. However, ecological microbial degradation is more beneficial, but electrolysis processes are more efficient as it showed up to $98 \%$ degradation of enoxacin [8]. Sulfonamide-degrading microorganisms [20] include Variovorax, Brevundimonas [86], and Pseudomonas [100]. FQs can undergo direct or indirect photolysis via the generation of ROS and photooxidation. Sulfonamides (halflife $<22$ d) degrade faster than FQs, whose half-life is much higher (half-life $>60 \mathrm{~d}$ ). FQs show slow degradation in the soil matrix due to the half-life $>60 d$ [25]. Lin et al. (2017) showed the photolytic degradation of ciprofloxacin and reported photo transformation, the formation of by-products, pathways, and mechanisms. FQs were found to be resistant to hydrolysis and biodegradation $[31,68]$. However, they are susceptible to phototransformation; hence photochemical transformation is supposed to be a great remediation strategy for surface water FQs contamination $[193,208,227,229]$ showed complete degradation of ciprofloxacin in the presence of bismuth oxybromide (BiObR), while minimal degradation was observed without $\mathrm{BiOBr}$ or irradiation. This degradation occurred with an oxidation reaction. Hence oxidation of contaminated aqueous bodies would be a great strategy to remediate the antibiotics. Hence $\mathrm{BiOBr}$ could be a potential photocatalyst for the removal of antibiotics. FQs undergo direct photolysis and self-sensitized photooxidation via ROS or by indirect photolysis by hydroxyl radicles [71]. The photo transformation pathways of some antibiotics are still unclear but in addition to hydroxyl radicle oxidation, the photochemical transformation of FQs including ciprofloxacin, danofloxacin, norfloxacin, marbofloxacin, and enrofloxacin, has been reported in the past few years [68, 71, 152, 171, 194, 214], and interestingly they were found to follow the first order photodegradation kinetics. Photodegradation of these FQs is dependent on factors like acid-base dissociations, the presence of different ionizable groups, and the $\mathrm{pH}$ of the surrounding environment. Here, the need to explore the complex network of FQs degradation pathways, mechanisms, affected metabolites of the biological system, and enzymatic relations enhance the knowledge and conceptual aspects of antibiotics remediation. Ge et al. [69] reported the highest photolysis efficiency is in the range of 6-9 in the euphotic zone of surface water. Therefore, instead of parent compounds, a photodegraded form of antibiotics, gatifloxacin, and balofloxacin were found in the surface water. Krzeminski et al. [111] also showed that membrane bioreactors and moving bed bioreactors could not remove antibiotics completely in most cases.
Constructed wetlands (CWs) may be an option for decreasing the antibiotic load from the environment and simultaneously, the antibiotic-resistant genes also [190]. These CWs were found to have the potential of removing ARGs (45-99\%) against sulfonamide, TC, and FQs [41, 91, 129, 153]. Alicycliphilus, due to its heterotrophic metabolism, can help in the remediation of hydrocarbons and metals. Bioremediation is possible because the microbe, in addition to nitrate and chlorate, uses oxygen as a terminal electron acceptor. The bacterial genus can potentially help in the bioremediation of different antibiotic classes. One of the studies by [192] showed the degradation of TC and OTC by Alicycliphilus [192]. A. denitrificans were reported to remove the TET up to $95 \%$ [201] and its analog OTC up to $70 \%$ [36]. It may be a promising approach in biotechnology due to its versatility and adaptation in aerobic and anaerobic conditions. Generally, antibiotics have a shorter half-life and are supposed to be metabolized in the body as they are found in the active form in the excretory waste. They are highly persistent and recalcitrant to degradation. Ciprofloxacin and Oxolinic acid were found to be less persistent (DT50 >90d), than the quinolones and sulfonamides (DT50 > $100 \mathrm{~d}$ ). The transferase enzyme (MurA) is the peptidoglycan precursors in bacterial cells, fosfomycin attacks it and inhibits the catalysis by covalent modification.

Different physical (ultrafilteration, adsorption), biological, photocatalytic, electrocatalytic, and chemical (oxidation, reduction) methods are used for antibiotic removal from the environmental matrices. However, these methods are not economical and produce secondary contaminants. The adsorptive removal of antibiotics from water has gained considerable attention as the process is relatively simple, does not cause any considerable pollution, and requires less energy [97]. Ion exchange resins and activated carbons are used as adsorbents but they are expensive and difficult to produce. Thus, the development of renewable and cheap sources including biomass is an alternative solution [12]. Biomass conversion commodity and fuels has gained attention as they can provide an eco-friendly and sustainable way to remove antibiotics from wastewater [102]. In a study by [96], a high-capacity adsorbent is used which was prepared by refluxing of the pine cones with concentrated sulfuric acid. The sulfuric acid was used for sulfonation and carbonization of pine cones. High adsorbtion capacity was observed for antibiotic TC and methylene blue. The adsorption of TC was shown to be increased at acidic $\mathrm{pH}$ and it at basic $\mathrm{pH}$ for methylene blue, wherease adsorption was favored with increasing temperature for both. The sulfuric acid treated pine cone $\left(\mathrm{PC}-\mathrm{SO}_{3} \mathrm{H}\right)$ showed better adsorption capacity then pristine pine cone. Similar adsorption capacities were found for the adsorption of both the pollutants from the 
tap water matrix [96].Sulfamethoxazole (SMX) is detected in environmental samples. It is bacteriostatic for the treatment of animal and human diseases. It is detected in the $\mathrm{ng} / \mathrm{L}$ range in wastewater and treatment plants. SMX can lead to drug resistance in microorganisms [2]. One of the studies by [2] used coffee waste (CW) derived CW-SO3H as a biosorbent to remove SMX from the aqueous solution. Coffee is one of the most consumed beverages all over the world which leads to the production of a large number of coffee residuals [169]. The sulfonated coffee waste was synthesized via the facile sulfonation method and characterized. The characterization revealed the biosorbent to be a negatively charged sulfonic acid functionalized carbonaceous material and can interact with SMX via electrostatic interactions. The biosorption process was spontaneous and exothermic because of the negative $\Delta G^{\circ}$ and negative $\Delta H^{\circ}$ values and the pseudo-second-order reaction best fits the biosorption data.

Nanocatalysts are used for the antibiotic remediation. They are cost-effective, eco-friendly, easy, cheap, and sustainable technology. [3] developed metallic iron nanoparticles having core-shell structured using coffee waste (Fe@BMC) at $800^{\circ} \mathrm{C}$ and characterized it. It showed properties as an electrocatalyst. The catalytic studies revealed that that the nanocatalyst is most effective as a catalyst for $95.72 \%$ of TC degradation in $45 \mathrm{~min}$. The reaction rate constant of $0.068 \mathrm{~min}^{-1}$. The porous carbon network and the interaction between the ultrathin carbon shell and the encapsulated metallic iron core are responsible for the catalytic behavior of nanocatalysts.

Fenton's reagent is used for antibiotic removal. Fenton's reagent is a mixture of ferrous salt and hydrogen peroxide used for the oxidation of the organics. It works better in acidic $\mathrm{pH}$ of $2.8-3$, as at $\mathrm{pH}$ greater than 3 the iron precipitates as iron hydroxide. Electro-Fenton (EF) is used to treat wastewater and an advanced oxidation process which relies on the electro generation of hydrogen peroxide in situ and the production of hydroxyl radicals in the presence of Fenton's catalyst. EF can also be called cold incineration as it allows the mineralization of organic pollutants to water, inorganic species, and carbon dioxide in aqueous media at atmospheric pressure and room temperature. $\mathrm{EF}$ allows the treatment of toxic and non-biodegradable effluents which are persistent and do not get oxidized by conventional processes. In EF process, hydrogen peroxide gets electrogenerated. Hydroxyl radicals are generated by both cathodic and anodic sources which work together to oxidize the organic pollutants via the abstraction of hydrogen or via hydroxylation. The successive oxidation leads to the production of organic acids with short chain such as oxalic acid and finally complete mineralization is reached [34]. EF processes provides the advantage of higher mineralization rate as compared to that of Fenton reaction or electrochemical oxidation. The regeneration of ferrous ion at the cathode makes this process highly efficient. EF processed are used for the treatment of heavily polluted wastewater which contain the persistent organic compounds and the hazardous waste at low cost and in with high efficiency.

\section{Transportation of antibiotics through mathematical ingression and sorption}

Antibiotics from different sources (domestic, hospitals, veterinaries, aquaculture, industries) contaminate the main sewage and reach the ground aquifers through leaching, with soil and water. The mobility of antibiotics in the soil is dependent on the sorption behavior of soil matter, which is estimated through the octanol-water partition coefficient $\left(K_{\text {ow }}\right): K_{\text {ow }}{ }^{1 / 4} \frac{1}{1} 2$ Solute_octanol $1 / 2$ Solute_Water. However, the sorption potential of antibiotics can be described by the soil-water partition coefficient $\left(K_{\mathrm{d}}\right)$, the ratio of the concentration of the compound in soil, and concentration dissolved in water. It is also useful to estimate the extent of antibiotic movement in ground and surface water; hence the use of $K_{d}$ value rather than $K_{\text {ow }}$ is more beneficial in sorption studies in soil matrices as the sorption coefficient always varies in the aqueous matrix. Hence, the data representation is always independent of one established mathematical modeling and is variable, depending on the sorption matrix. Hence, $K_{\mathrm{d}}$ and $K_{\mathrm{f}}$ (Freundlich sorption constant) values are used to deliver the correct data, but $K_{\mathrm{f}}$ is always better in estimating the partitioning.

The leaching of antibiotics to groundwater aquifers can be calculated by the ratio of tritium and helium $(3 \mathrm{H} / 3 \mathrm{He})$ in the water [175].

$t_{\mathrm{H}}^{3} / 3_{\mathrm{He}}=\lambda^{-1} \ln \left({ }^{3} \mathrm{He} * /{ }^{3} \mathrm{H}+1\right)$

Antibiotic contamination assessment to groundwater is the call of the current situation of antibiotic resistance and the failure of antibiotics. The groundwater quality can be accessed by monitored through groundwater oxidation capacity (OXC) in the context of present nitrates and sulfates.

$\mathrm{OXC}=5\left[\mathrm{NO}_{3}^{-}\right]+3.5\left[\mathrm{SO}_{4}^{2-}\right]$

The OXC can be explained by its behavior to oxidize the reduced compounds through redox reactions. The equation was successfully applied to determine the groundwater contamination in the Netherlands [228]. Hence, the concentration of antibiotics might get influenced by redox conditions. Antibiotics can also be transported or contaminate other environments by aerial transport with 
particulate matter [143], through rainfall and soil erosion, through eroded soil of unpaved roads [204]. Interestingly, erosion can be accounted for as an erosion rate of $394.6 \mathrm{Mg} \mathrm{km}^{-2}$ year $^{-1}$ [203].

Sorption is one of the main factors in antibiotic remediation. It determines the antibiotics' behavior and fate in the soil environment [210]. It has shown that the FQs sorption in different kinds of soils (sandy loam, loam, clay loam, sand, loamy sand, silt sand, silt clay loam) is very high due to very high $K_{d}$ values [213]. Still, it depends upon soil texture and cation exchange properties of soil. Antibiotic sorption efficiency may depend on the hydrophobic partition, hydrogen bonding, ionic exchanges, and bridging and the $\mathrm{pH}$, quality, and minerals present with the matrix. Hydrophobic partition and non-hydrophobic interaction of antibiotics are always the key results of antibiotic sorption in soil [104]. Soil sorption of ionizable antibiotics also depends on their electrostatic interaction and hydrogen bonding. The transportation of antibiotics in soil depends upon their mobility, reactivity, and bioavailability, microbial communities, microbial products, soil buffering capacity, soil texture, etc. Some antibiotics are nonpolar or hydrophobic, whereas others get dissociated easily depending on soil $\mathrm{pH}$.

Therefore, the properties of the compounds and environmental factors are the deciding factor for the antibiotics' adsorption. The adsorption behavior depends mainly on the functional groups and structure of the antibiotics. Quinolones and TET have ionic groups and strong polarity, which is mainly responsible for its high adsorption. Enrofloxacin, norfloxacin, and ciprofloxacin show strong adsorption to the soil surface. Ciprofloxacin structure includes one bond each of $-\mathrm{N}(\mathrm{CH} 3)_{2},-\mathrm{C}=\mathrm{O},-\mathrm{CONH}_{2}$, and $-\mathrm{COOH}$ group, which contributes to its high adsorption [105]. The - $\mathrm{COOH}$ group is mainly responsible for the adsorption properties of the quinolones, as two orders of magnitude in enrofloxacin reduced the adsorption capacity without the $-\mathrm{COOH}$ group [154]. TET can adsorb on the surface of soil because of the electrostatic attraction between the negatively charged site of adsorption and positively charged group $\left(-\mathrm{NH}\left(\mathrm{CH}_{3}\right)_{2}\right)[60]$.

The adsorption in the soil is dependent on $\mathrm{pH}$. At environmental $\mathrm{pH}$, antibiotics can exist as zwitterions, anions, and cations [183]. $K_{\text {ow }}$ of antibiotics varies in a $\mathrm{pH}$ range, which is around the acid dissociation constant [134]. The montmorillonite adsorption for TET decreases with an increase in $\mathrm{pH}$ [172]. Furthermore, the type of soil also determines the adsorption behavior of the same antibiotic. $K_{\mathrm{d}}$ values vary of metronidazole, and tylosin varies with the type of soil being used. Sulfamethazine adsorption is also affected by the soil $\mathrm{pH}$, as the $\mathrm{pH}$ increased the $K_{\mathrm{d}}$ value decrease, and the $K_{\mathrm{d}}$ value increase with high organic carbon [120].

\section{Uptake by plants}

Vegetables are an essential part of our daily diet. Due to the reach of antibiotics in the water ecosystem, their presence in vegetables was investigated. Antibiotic exposure to humans through plant-based food (e.g., vegetables) helps in antibiotic transportation in the food chain [42]. These antibiotics, when entering the food chain, contribute to antibiotic resistance among microbial communities. However, from the view of remediation, the higher accumulator plants can be used as the biological tools in remediation. Physiochemical and mineralogical properties of antibiotics include water solubility, dissociation coefficient, partition coefficient, Henry's law constant, soil properties, water quality, nature of the antibiotics, charge, lipophilicity hydrophobicity, acidity, volatility, and sorption potential. These physicochemical and mineralogical properties of antibiotics these properties determine their uptake by plants.

The hydrophobicity $\log K_{\text {ow }}$ and extent of ionization may be the reason for variation in accumulation and their translocation in a plant system. These physical and chemical properties describe the neutral or ionizable forms of antibiotics at different environmental matrices and $\mathrm{pH}$. For example, carbamazepine uptake is found mainly in the plant leaves $(<52 \mu \mathrm{g} / \mathrm{g})$ rather than plant roots, and it is due to the passive translocation along with its neutrality. The lesser $\log K_{\text {ow }}$ enables it to move via instance roots to be accumulated in matured leaves. While triclosan, an antibacterial agent movement, falls on the upper tail of Gaussian distribution due to the slightly ionizable form, the neutral form of sulfamethazine would not enter the root system because of the low log $K_{\text {ow }}$ (0.9). Not every chemical can influence plant physiology; it depends on the physicochemical behavior of a particular chemical/pollutant [140]. However, plants uptake the antibiotics from soil and water as a part of their normal physiology, but they tend to experience some negative effects on their physiology. Vegetables carry antibiotic contamination at far below the MIC and carry it forward to the ecological food web, which can lead to bacterial resistance against antibiotics. The plant growth can be compromised on both above and below ground level under the stress of organic pollutants, above-ground effects are more critical as the young leaves get sacrificed. Antibiotics metabolism in plants recently reported being accelerated due to the increased resistance, e.g., Typha [52]. Pharmaceuticals can be taken up by plants in concentrations high enough to use these plants as phytoremediation agents, e.g., lettuce, carrots, potatoes, tomatoes, cucumber, and green beans [33]. The red cabbage is found to be the reservoir 
of veterinary antibiotics, e.g., enrofloxacin, chlortetracycline, amoxicillin, monensin, and growth inhibition of red cabbage observed under monensin stress. Red cabbage roots, stem, and leaves were studied and found to be a main reservoir/collector of antibiotic residues of chlortetracycline. Enrofloxacin was reported to inhibit/ altered photosynthesis [9]. Phytoremediation can be useful for antibiotic remediation, but plants always have to pay a cost in terms of reduced photosynthesis and consequently reduced growth $[76,77,79]$.

Not all antibiotics reach every part of a plant; their movement depends on the physiological and mineralogical properties. For example, ciprofloxacin, a product of enrofloxacin, is only found in the stem [42]. Several plants are studied to check their potential for antibiotic remediation, including the consumable plants, e.g., red cabbage, white cabbage, radish, and ryegrass [32]. Plant metabolic enzymes ion channel, or ATP-dependent pumps, help remove toxic substances from them. But the accumulation of antibiotics in plant root, shoot, leaf, stem or fruit, postulates that antibiotics may alter these important working units of the plant system. Pharmaceuticals (PCs) were also evaluated in cucumber and tomato for their translocation, accumulation, and effects on plant organs. The treated wastewater results in decreased bioavailability of ionic PCs in plants rather than the contaminated freshwater, and it indicates the positive side for using the treated wastewater for irrigation [73]. The red cabbage was found to be the reservoir of antibiotics and helps in their carrier in the food chain. Plants do not support the non-ionic PCs transportation in the cell due to maybe repulsion forces exerted by negatively charged cell wall \& cytosolic molecules; therefore, they might get accelerated in fruits rather than leaves [73].On harvesting, red cabbage was found to contain the chlortetracycline up to $17 \mu \mathrm{g} / \mathrm{kg}$ of fresh weight (FW). Red cabbage roots, stem, or leaves were studied and found as a main reservoir/collector of antibiotic residues of chlortetracycline. Enrofloxacin was supposed to inhibit/alter photosynthesis $[9,101]$. The enrofloxacin stressed plants showed faded yellow leaves. However, the concentration of antibiotics above ground level was found much lower than below ground (roots) and the stem. PCs have been detected in the soil matrix. The potential of carbamazepine and sulfamethazine for the uptake by crops has been studied to investigate the plant-soil relation under the antibiotic stress, e.g., radish and ryegrass, and interestingly they found the carbamazepine uptake as $52 \mu \mathrm{g} / \mathrm{g}$ and $33 \mu \mathrm{g} / \mathrm{g}$ respectively by both, radish and ryegrass [9]. While the sulfamethazine was reported below the LOQ $(<0.01 \mu \mathrm{g} / \mathrm{g})$, both the antibiotics were detected in the spiked water even after seven days, which also supports the physical availability of antibiotics and their incomplete remediation through the plant system. Here the need for a microbial enzyme system is found as an alternative in the complete removal of antibiotics.

\section{Bacterial strategies and scope to overcome the antibiotic load}

The easy reach, availability, and use of antibiotic compound by humans has resulted in the emergence of resistance among the bacterial communities in the environment, and the risk of owing pathogenic bacterial diseases through the reuse of contaminated water (for irrigation) cannot be neglected $[6,158]$. Bacteria can degrade a variety of organic pollutants/hydrocarbon, e.g., chlorpyrifos, parathion [159], petroleum oil [22]. Hence, the approach of antibiotic degradation by bacteria is vital for maintaining ecological resilience. Strains of Bacillus and Chryscobacterium are the known potential bacteria for organic pollutants degradation, including the antibiotic, sulfanilamide $[174,219]$. A study by [113] showed the use of Serratia sp. for the degradation of penicillin from the River Yamuna [113].

Although bacteria residing in different matrices are continuously in close contact with the contaminants, bacteria survive due to certain molecular mechanisms, e.g., the mutation in antibiotic target molecules, overexpression of drug efflux pumps, and foreign gene acquisition are among the major mechanisms of antibiotic resistance. Still, in addition to these, there are more ways to overcome the effect of antibiotics (Fig. 1). Immediate cellular responses were observed to these stressors (antibiotics), e.g., ATPdependent efflux pumps and osmolarity regulator outer proteins $[17,122,163]$.

Integron is a comparatively novel transfer system for genes that may contribute to multi-resistance in bacterial communities. The bacteria-harboring ARG's also persisted throughout all stages of wastewater treatment and found to be better surviving than total bacterial load even after the chlorination processes [137]. WWTPs are not capable enough to remove the existing bacterial populations as the $E$. coli detection was found to be 2.3-3.3 log unit reduction only, and beta-lactam along with quinoloneresistant bacteria was observed as a $6 \%$ change in influent and effluents. E. coli was the most affected multidrugresistant (MDR) isolate, among others, while resistance was also seen against sulfamethoxazole, ciprofloxacin, trimethoprim, with the prevalence value of $30 \%[6,133$, 155]. But there is a significant difference among these prevalence values as [21] reported it as $20 \%$ in the effluent wastewater. The heterotrophic population of bacteria were selected seasonally and found that these MDR bacteria were ranging between 5 and $64 \%$ and confirmed by the presence of tet genes (tetO, $W, H, Z, Q$ ) in the chlorinated 


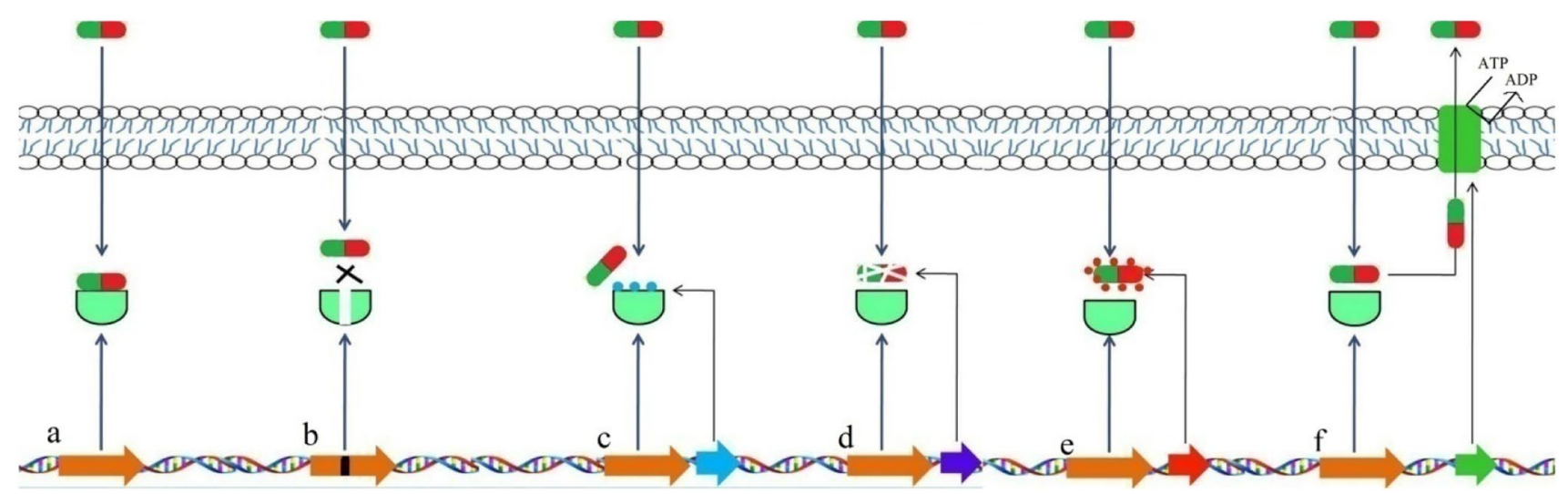

Fig. 1 Antibiotic resistance development in bacterial cell; a The normal mechanism of antibiotic and its target interaction while in the resistant bacteria $\mathbf{b}$ target gene may be mutated or $\mathbf{c}$ target protein/molecules may be masked by other protein/molecules (in response to antibiotic stress) or $\mathbf{d}$ the direct/indirect degradation may occur or e modification of antibiotic or $\mathbf{f}$ The efflux of antibiotics from the bacterial cell through ATP-dependent efflux pumps may operate to provide the resistance to a bacterial cell effluents. Simultaneously, even after chlorination, the ARGs (tetA, EBGHTSX) (sul1,2), ermC, qnrB were discharged in the effluent, which is quite higher than influents [4]. These ARGs can be removed by the biological treatment following ultraviolet radiation. Mao et al. [137] observed a $90 \%$ reduction in the total ARGs., in 2015 from influent to effluent in conventional activated sludge (CAS), while ARGs were found abundantly in WWTPs effluents [216] Furthermore, Vibrio fischeri and E.coli faced enormous toxicity against FQs, which may finally disturb the microbial activities in the aquatic environment due to the enhanced phototoxic effects of FQs $[68,71]$. ARBs can be found in different environmental matrixes, e.g., soil, water, dust, food, insects, and wildlife [42]. World Health Organization (WHO) has declared a list of the urgent threat of antibiotic-resistant bacteria, e.g., multidrug-resistant Mycobacterium; carbapenem-resistant Pseudomonas baumannii, Pseudomonas aeruginosa, Klebsiella pneumonia, E. coli, Enterococcus sp., Serratia sp., Proteus sp., Providencia sp., Morganella sp.; Methicillin-resistant Staphylococcus aureus; vancomycin-resistant Enterococcus faecium; ampicillin-resistant Haemophilus influenza; FQs-resistant Campylobacter; clarithromycin resistant Helicobacter pylori; and Shigella sp.; penicillin-non susceptible Streptococcus pneumoniae; FQs and cephalosporin-resistant Neisseria gonorrhea, recommends the research and discoveries of new antibiotics. Some bacteria are have already developed resistance against the antibiotic fosfomycin, e.g., Mycobacterium tuberculosis, Escherichia coli, and Borrelia burgdorferia encode aspartic acid instead of cystine in the active site of the MurA enzyme. At the same time, many became resistant by acquiring resistance through horizontal gene transfer or bacterial genetic machinery or its products.

Microbial communities are under the direct (shortterm) and indirect (long-term) stress of antibiotics in the environment. Direct stress involves bactericidal and bacteriostatic effects and sometimes leads to the disappearance of the whole microbial community, while indirect stress includes the development of antibiotic resistance in bacteria. Earlier it was suggested that the selection of resistant bacteria occurred, on direct contact with high antibiotic flux by the bacteria, but it's now clear that the continuous exposure of antibiotics (usually finds in wastewater is the main reason for bacterial evolution and resistance [44].

\section{Evolutionary host for resistance emergence and its spread}

The "persistence" and "viable but non-culturable" (VNBC) mode of bacterial evolution makes them special under stress/toxic conditions [11]. However, VBNC and antibiotic resistance (AR) were discovered with a time gap of decades, but they share some similarities, e.g., the formation of VBNC and persistent antibiotic cells, presence of biofilm and antibiotic tolerance, stringent responses, proteolysis, toxin-antitoxin systems, ATP depletion, and dormancy. These mechanisms promote the fitness of survived resistant mutants of bacterial populations under the influence of their genetic rearrangements [11]. Once the resistance is developed in bacteria, it is less likely to revert in the absence of antibiotic load or stress, because fitness and selection are unidirectional and evolution cannot be operated backward [191]. Ahmed et al. [1] have shown the evolution of bacteria from biofilms against the ciprofloxacin at sub-inhibitory concentrations $(0.1 \mathrm{mg} / \mathrm{l})$. [173] reported the dangerous situation of antibiotic resistance, and it indicates that the consumption of antibiotics in China is above the threshold and may result in some multi antibiotic-resistant "superbug." The non-lethal concentration of FQs, aminoglycosides, and 
beta-lactam can increase the resistance level due to an increased mutation rate, which ultimately interferes with normal homologous recombination and stimulates the horizontal gene transfer (HGTs). This new genetic variation may lead to high-level resistance even at sub-MICs [99]. The resistant bacteria are a threat to the human, animals, and ecosystem and are high-risk organisms listed in [35] report, e.g., Drug-resistant Neisseria gonorrhoeae, Campylobacter, Enterococcus, Candida, Enterobacteriaceae, Clostridium difficile, Non-typhoidal Salmonella, Shigella, Salmonella typhi, Staphylococcus aureus, Tuberculosis, Group B Streptococcus, Group A Streptococcus, Streptococcus pneumonia and multidrug-resistant beta-lactamase-producing Enterobacteriaceae, Pseudomonas aeruginosa and Acinetobacter [35]. They all can cause acute and persistent infections. The level of antibiotic resistance in the USA is at a very critical point as the vancomycin-resistant Enterococcus faecium showed the MICs, $>1.024 \mu \mathrm{g} / \mathrm{mL}$ for fosfomycin and it is interestingly noted that this high-level resistance is due to the major substitution mutation as CYS1 19ASP in the active site of MurA enzyme. This scenario indicates the current need for surveillance activities to check, aware, and minimize the target antibiotic contamination and prevent the spreading of antibiotic resistance among bacteria. Fecal contamination is the main source for the spreading of zoonotic bacteria due to direct contact with the animal-based food product, e.g., meat [54]. The American consumer is not in direct contact with farm animals; rather, the antibiotic-resistant bacteria were found from the human population. Hence, it is clearly said that the indirect transfer through plasmids and transposons is critically responsible for infection among other microbial communities. In the European Union, Campylobacteriosis was found in 246307 cases in 2016, which shows the level of resistance, and the spread of this bacteria continues to rise $[55,56]$. In addition to resistance against the particular antibiotics, bacteria also show cross-resistance, and it might be possible that it happens when bacteria survive in multidrug stress in the environment. Campylobacter sp., the common agent of gastroenteritis, has shown individual and cross-resistance against ciprofloxacin, TET, and erythromycin. Campylobacter transmission to the human population is mainly due to poultry farming [103], and it also shows the cross-resistance with TET by binding with the TetO protein of the ribosomal A site. This tetO gene was associated with TET resistance, as described by lovine [94]. However, it was also found to be resistant (C. jejuni and C. coli) against ciprofloxacin through the point mutation in quinolone resistance determining region of GyrA protein [94]. Ciprofloxacin, TET, and erythromycin resistance through the multidrug efflux pumps are predominantly active in the resistant bacteria $[94,217]$. The erythromycin resistance was found to be associated with mutations in 235 rRNA, L22, and L4 proteins of ribosomes [83]. In addition to other physiochemical properties, the resistance and crossresistance are also achieved by variation in temperature, e.g., E. coli. Interestingly, the Thr86lle Gyr A mutation was found to be responsible for the variability in FQs resistance. A2075G mutation in the $23 \mathrm{~S}$ rRNA gene is also responsible for erythromycin resistance. The efflux pumps do not govern bacterial resistance; rather, they are developed by the point mutations at specifics sites. Generally, antibiotic treatment is not recommended for Campylobacteriosis but is sometimes given to immunocompromised individuals. Human to human transmission is not frequent and normally occurs by meat, contaminated water, and unpasteurized milk consumption [94]. From 2013 to 2016, Campylobacter jejuni was the frequently found bacterial sp. with high antibacterial resistance, while $C$. concisus and $C$. fetus were least detected $[55,56]$.

\section{Detection of antibiotics in the environmental matrices}

Their detection has confirmed the presence and risk of active antibiotics in the supply of water Detection of antibiotics are mostly seen under MICs, but still, resistance is reported to be increased. It is most obvious that the detection and actual present concentrations may vary because there is always a possibility of in-process degradation by the stored enzymes which come out during the homogenization of plant tissues. Carbamazepine $(52 \mu \mathrm{g} / \mathrm{g}$ in radish \& $33 \mu \mathrm{g} / \mathrm{g}$ in ryegrass), sulfamethazine $(<0.01 \mu \mathrm{g} / \mathrm{g}$ by radish \& ryegrass) has been detected in soil [32]. Beta-lactams are water-soluble antibiotics and easily transformed through hydrolysis, despite the high consumption, neither penicillin $\mathrm{G} / \mathrm{V}$ nor amoxicillin was detected in wastewater. The ampicillin was detected up to $75.40 \mathrm{ng} / \mathrm{L}[93,109,161]$ reported ampicillin up to $1805 \mathrm{ng} / \mathrm{L}$ in WWTPs in Greece. Amoxicillin can get hydrolyzed in animals [176], but in the presence of methanol, it can form complex as AMO-MEOH adduct, and it was confirmed by LC-MS/MS [80]. The traces were found in root samples of the plant but not in plant tissues. FQs were the most abundant antibiotics found in WWTP influents enrofloxacin $(400.20 \mathrm{ng} / \mathrm{L})$, ofloxacin (175.01 ng/L), ciprofloxacin (330.33 ng/L) in domestic wastewater ciprofloxacin (639 ng/L), ofloxacin $(529 \mathrm{ng} / \mathrm{L})$, and enrofloxacin (below LOD) [178]. The WWTP's are not efficient for the complete removal of antibiotics [127, 128, $145,170]$, but the Hazard quotient $(\mathrm{HQ})$ for the estimation of risk of WWTPs effluents on the environment can be calculated by the ratio of measured concentration (MEC) and predicted no-effect concentrations (PNEC) $[H Q=(M E C) /$ (PNEC)], described by European community guidelines [56, 58]. Table 1 shows the mass spectrometry techniques for the detection of antibiotics in the environmental matrices. 
Table 1 The mass-spectrometry based techniques for the detection of antibiotics in different environmental matrices

\begin{tabular}{|c|c|c|c|c|}
\hline S. No. & Antibiotic & Detection & Matrix & References \\
\hline 1. & $\begin{array}{l}\text { Cefdimir } \\
\text { Sulfonamide } \\
\text { Sulfaguanidine } \\
\text { Sulfathiazole } \\
\text { Sulfamethoxazole } \\
\text { Ciprofloxacin } \\
\text { Sulfanilamide }\end{array}$ & LC-ESI-MS/MS & $\begin{array}{l}\text { Liquid matrix } \\
\text { River water } \\
\text { Activated sludge } \\
\text { Microbial culture } \\
\text { Microbial liquid biomass }\end{array}$ & $\begin{array}{l}\text { Selvi et al. [188], Sági et al. [180], Liao } \\
\text { et al. [124, 125] }\end{array}$ \\
\hline 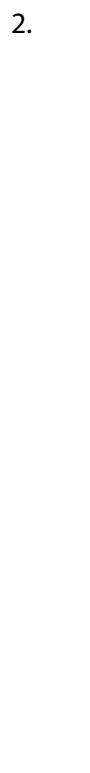 & $\begin{array}{l}\text { Sulfamethoxazole } \\
\text { Sulfadimethoxine } \\
\text { Sulfamethazine } \\
\text { Enrofloxacin } \\
\text { Ceftiofur } \\
\text { Oxytetracycline } \\
\text { Chlortetracycline } \\
\text { Tetracycline } \\
\text { Tetracycline } \\
\text { Sulfathiazole } \\
\text { Ampicillin } \\
\text { Norfloxacin } \\
\text { Ciprofloxacin } \\
\text { Danofloxacin } \\
\text { Enrofloxacin } \\
\text { Sulfadiazine } \\
\text { Sulfamethoxazole } \\
\text { Sulfachloropyridazine } \\
\text { Sulfadimidine } \\
\text { Sulfathiazole } \\
\text { Sulfamethazine } \\
\text { Enoxacin }\end{array}$ & HPLC & $\begin{array}{l}\text { Liquid/aqueous matrix } \\
\text { Microbial culture } \\
\text { Waste water } \\
\text { Sludge } \\
\text { Waste water } \\
\text { Soil } \\
\text { Aqueous matrix } \\
\text { Waste water }\end{array}$ & $\begin{array}{l}\text { Yang et al. [222], Diago et al. [51], } \\
\text { Chen et al. [40], Park and Choung } \\
\text { [162], Pereira et al. [167], Pan et al. } \\
\text { [160], Annabi et al. [8] }\end{array}$ \\
\hline 3. & $\begin{array}{l}\text { Enoxacin } \\
\text { Cefalexin } \\
\text { Ampicillin } \\
\text { Sulfamethoxazole } \\
\text { Sulfadiazine } \\
\text { Norfloxacin } \\
\text { Ofloxacin } \\
\text { Ciprofloxacin } \\
\text { Tetracycline } \\
\text { Roxithromycin } \\
\text { Erythromycin } \\
\text { Trimethoprime }\end{array}$ & UPLC-MS/MS & $\begin{array}{l}\text { Surface water } \\
\text { Sludge }\end{array}$ & $\begin{array}{l}\text { Annabi et al. [8], Dai et al. [45], Li and } \\
\text { Zhang [123] }\end{array}$ \\
\hline
\end{tabular}


Table 1 (continued)

\begin{tabular}{|c|c|c|c|c|}
\hline S. No. & Antibiotic & Detection & Matrix & References \\
\hline 4. & $\begin{array}{l}\text { Sulfamethazine } \\
\text { Enrofloxacin } \\
\text { Ciprofloxacin } \\
\text { Monensin } \\
\text { Fluoxetine } \\
\text { Carbamazepine } \\
\text { Propranolol } \\
\text { Sulfamethazine } \\
\text { Triclosan } \\
\text { Sulfamethoxazole } \\
\text { Sulfapyridine } \\
\text { Naproxen } \\
\text { Ibuprofen } \\
\text { Gemfibrozil } \\
\text { Clofibric acid } \\
\text { Ketoprofen } \\
\text { Bezafibrate } \\
\text { Metoproloi } \\
\text { Caffeine } \\
\text { Sildenofil } \\
\text { Lamotrigine } \\
\text { Carbamazepine } \\
\text { Sulfamethoxazole } \\
\text { Sulfadimethoxine } \\
\text { Sulfamonomethoxine }\end{array}$ & LC-MS/MS & $\begin{array}{l}\text { Soil } \\
\text { Red cabbage } \\
\text { White cabbage Radish \& Rye grass } \\
\text { (root, stem, and leaves) } \\
\text { Soil and water matrix } \\
\text { Tomato \& cucumber (fruits, leaves, } \\
\text { soil, clay sand) } \\
\text { Waste water sludge }\end{array}$ & $\begin{array}{l}\text { Topp et al. [205], Choudhary et al. } \\
\text { [42], Grote et al. [78], Carter et al. } \\
\text { [32], Goldstein et al. [73], Yang et al. } \\
\text { [221] }\end{array}$ \\
\hline 5. & $\begin{array}{l}\text { Sulfamonomethoxine } \\
\text { Sulfachloropyridazine } \\
\text { Sulfamethazine } \\
\text { Trimethoprim } \\
\text { Norfloxacin } \\
\text { Ofloxacin } \\
\text { Lincomycin } \\
\text { Leucomycin } \\
\text { Oxytetracycline } \\
\text { Norfloxacin }\end{array}$ & UPLC-ESI-MS/MS & $\begin{array}{l}\text { Waste water } \\
\text { irradiated aquous solution }\end{array}$ & Chen et al. [40] \\
\hline 6. & $\begin{array}{l}\text { Norfloxacin } \\
\text { ciprofloxacin }\end{array}$ & UV/Vis spectrophotometer & $\begin{array}{l}\text { Aerobic and anaerobic sludge of } \\
\text { bioreactor } \\
\text { Soil }\end{array}$ & $\begin{array}{l}\text { Santos and Ramos [182], Zhang et al. } \\
\text { [226] }\end{array}$ \\
\hline 7. & $\begin{array}{l}\text { Levofloxacin } \\
\text { Lincomycin } \\
\text { Linezolid } \\
\text { Marbofloxacin } \\
\text { Sarafloxacin }\end{array}$ & LC-UV-MS & Aqueous media & Bergheim et al. [19] \\
\hline 8. & Sulfamethoxazole & LC-ToF-MS/MS & Microbial culture & Miran et al. [146] \\
\hline 9. & $\begin{array}{l}\text { Sulfamethoxazole } \\
\text { Sulfadimidine } \\
\text { Sulfapyridine } \\
\text { Sulfadiazine } \\
\text { Sulfathiozole } \\
\text { Sulfamethazine } \\
\text { Tylosin } \\
\text { Chlortetracycline } \\
\text { Ciprofloxacin } \\
\text { Norfloxacin } \\
\text { Tetracycline }\end{array}$ & HPLC-UV/Vis & $\begin{array}{l}\text { Microbial culture } \\
\text { Soil } \\
\text { Aqueous solution } \\
\text { Gamma } \\
\text { Sludge } \\
\text { Soil } \\
\text { Liquid matrix }\end{array}$ & $\begin{array}{l}\text { Mao et al. [138], Topp et al. [205], } \\
\text { Zhang et al. [227, 229], Jiang et al. } \\
\text { [100] }\end{array}$ \\
\hline
\end{tabular}


Table 1 (continued)

\begin{tabular}{|c|c|c|c|c|}
\hline S. No. & Antibiotic & Detection & Matrix & References \\
\hline 10. & $\begin{array}{l}\text { Salbutanol } \\
\text { Atenolol } \\
\text { Ranitidine } \\
\text { Lincomycin } \\
\text { Ofloxacin } \\
\text { Cyclophosphamide } \\
\text { Carbamazepine } \\
\text { bezafibrate }\end{array}$ & SPE-LC-MS/MS & $\begin{array}{l}\text { Eruca sativa L. and Zea mays L. } \\
\text { (Leaves and Kernels) }\end{array}$ & Marsoni et al. [140] \\
\hline 11. & $\begin{array}{l}\text { Gatifloxacin } \\
\text { Balofloxacin } \\
\text { Norfloxacin } \\
\text { Enrofloxacin } \\
\text { Ciprofloxacin } \\
\text { Fluoroquinolone } \\
\text { Ofloxacin } \\
\text { Cefalexin } \\
\text { Tetracycline } \\
\text { Chloramphenicol } \\
\text { Erythromycin } \\
\text { Trimethoprim } \\
\text { Roxithromycin } \\
\text { Tylosin } \\
\text { Levofloxacin } \\
\text { Sulfamethazine } \\
\text { Sulfathiazole } \\
\text { Sulfamethoxazole } \\
\text { Amoxicillin } \\
\text { Cefotaxime } \\
\text { Oxytetracycline }\end{array}$ & HPLC-ESI-MS/MS & $\begin{array}{l}\text { Water } \\
\text { River water } \\
\text { Waste water } \\
\text { Synthetic water } \\
\text { Liquid matrix }\end{array}$ & $\begin{array}{l}\text { Ge et al. [70], Babic et al. [13], Leung } \\
\text { et al. [121] }\end{array}$ \\
\hline 12. & $\begin{array}{l}\text { Sulfamethoxazole } \\
\text { Sulfamethazine } \\
\text { Lincomycin } \\
\text { Chloramphenicol } \\
\text { Sulfadiazine } \\
\text { Doxycycline } \\
\text { Oxytetracycline } \\
\text { Tetracycline } \\
\text { Trimethoprim } \\
\text { Amoxicillin } \\
\text { Cefuroxime } \\
\text { Azithromycin } \\
\text { Clarithromycin } \\
\text { Erythromycin } \\
\text { Roxithromycin } \\
\text { Tylosin } \\
\text { Flumequine } \\
\text { Levofloxacin } \\
\text { Furazolidone } \\
\text { Sulfachloropyridazine } \\
\text { Ofloxacin }\end{array}$ & $\begin{array}{l}\text { LC-MS/MS } \\
\text { ESI-POS/NEG(MRM)-SPE }\end{array}$ & Water & Kivits et al. [107] \\
\hline 13. & Ciprofloxacin & HPLC-MS & Aqueous solution & Zhang et al. [227, 229] \\
\hline 14. & $\begin{array}{l}\text { Ciprofloxacin } \\
\text { Sulfamethoxazole }\end{array}$ & SPE-LC-MS & Ground water & Ji et al. [99] \\
\hline
\end{tabular}


Table 1 (continued)

\begin{tabular}{|c|c|c|c|c|}
\hline S. No. & Antibiotic & Detection & Matrix & References \\
\hline 15. & $\begin{array}{l}\text { Erythromycin } \\
\text { Roxithromycin } \\
\text { Tylosin } \\
\text { Norfloxacin } \\
\text { Ciprofloxacin } \\
\text { Enrofloxacin } \\
\text { Levofloxacin } \\
\text { Sulfamethoxazole } \\
\text { Sulfamethazine } \\
\text { Sulfaquinoxaline } \\
\text { Oxytetracycline }\end{array}$ & UPLC & Manured soil & Camotti Bastos et al. [30] \\
\hline 16. & Ciprofloxacin & HPLC-FDA & Water samples & Baginska et al. [15] \\
\hline 17. & $\begin{array}{l}\text { Ofloxacin } \\
\text { Norfloxacin } \\
\text { Ciprofloxacin }\end{array}$ & UFLC & Microbial culture & Amorim et al. [7] \\
\hline 18. & $\begin{array}{l}\text { Ciprofloxacin } \\
\text { Difloxacin } \\
\text { Enrofloxacin } \\
\text { Levofloxacin } \\
\text { Lomefloxacin } \\
\text { Norfloxacin } \\
\text { Ofloxacin } \\
\text { Orbifloxacin } \\
\text { Sarafloxacin } \\
\text { Fleroxacin } \\
\text { Gatifloxacin } \\
\text { Moxifloxacin }\end{array}$ & HPLC-FLD & Waste water & He and Blaney [85] \\
\hline 19. & $\begin{array}{l}\text { Ciprofloxacin } \\
\text { Tetracycline } \\
\text { Doxycycline } \\
\text { Sulfamethazine } \\
\text { Sulfamethoxazole } \\
\text { Clindamycin } \\
\text { Ofloxacin } \\
\text { Norfloxacin } \\
\text { Sulfanilamide }\end{array}$ & LC-MS/MS-ESI & $\begin{array}{l}\text { Biosolids } \\
\text { Microbial culture } \\
\text { Aquous solution } \\
\text { Solid and aqueous solution }\end{array}$ & Wu et al. [218], Amorim et al. [7] \\
\hline 20. & $\begin{array}{l}\text { Ciprofloxacin } \\
\text { Piromidic acid } \\
\text { Norfloxacin } \\
\text { Pipemidic acid } \\
\text { Ofloxacin } \\
\text { Moxifloxacin }\end{array}$ & UPLC-MS/MS-ESI & Waste water & García-Fernández et al. [66] \\
\hline 21. & $\begin{array}{l}\text { Tetracycline } \\
\text { Streptogramin }\end{array}$ & Electrochemical ELISA's & Microfluid & Kling et al. [108] \\
\hline
\end{tabular}


Table 1 (continued)

\begin{tabular}{|c|c|c|c|c|}
\hline S. No. & Antibiotic & Detection & Matrix & References \\
\hline 22. & $\begin{array}{l}\text { Azithromycin } \\
\text { Clarithromycin } \\
\text { Erythromycin } \\
\text { Roxithromycin } \\
\text { Tylosin } \\
\text { Cefaclor } \\
\text { Ampicillin } \\
\text { Tetracycline } \\
\text { Chlortetracycline } \\
\text { Oxytetracycline } \\
\text { Ciprofloxacin } \\
\text { Ofloxacin } \\
\text { Enrofloxacin } \\
\text { Norfloxacin } \\
\text { Sulfamethazine } \\
\text { Sulfamethoxazole } \\
\text { Sulfadiazine } \\
\text { Trimethoprim } \\
\text { Chloramphenicol } \\
\text { Florfenicol } \\
\text { Thiamphenicol }\end{array}$ & $\begin{array}{l}\text { SPE } \\
\text { UPLC-Q/TOF/MS }\end{array}$ & Urine & Wang et al. $[209,211]$ \\
\hline 23. & $\begin{array}{l}\text { Lincomycin } \\
\text { Gentamycin } \\
\text { Kanamycin } \\
\text { Streptomycin } \\
\text { neomycin }\end{array}$ & Immunochromatographic assay & Milk & Peng et al. [166] \\
\hline 24. & $\begin{array}{l}\text { Oxytetracycline } \\
\text { Chloramphenicol } \\
\text { Kanamycin } \\
\text { Streptomycin } \\
\text { Tetracycline } \\
\text { Penicillin G } \\
\text { Doxycycline } \\
\text { Aminoglycoside } \\
\text { Amoxicillin } \\
\text { Fluoroquinolone } \\
\text { Erythromycin }\end{array}$ & $\begin{array}{l}\text { Biosensor, optical, electrochem- } \\
\text { ical and nanomaterials }\end{array}$ & & Lan et al. [116] \\
\hline 25. & $\begin{array}{l}\text { Chloramphenicol } \\
\text { Kanamycin } \\
\text { Oxytetracycline } \\
\text { Thiamphenicol }\end{array}$ & Microchip electrophoresis & Food & Zhou et al. [230] \\
\hline 26. & Ciprofloxacin & $\begin{array}{l}\text { Biosensor } \\
\text { UV/Vis }\end{array}$ & Microbial liquid & Pawar et al. [164] \\
\hline 27. & $\begin{array}{l}\text { Kanamycin } \\
\text { Chloramphenicol }\end{array}$ & Electrochemical aptasensor & Microfluid & Huang et al. [91] \\
\hline 28. & $\begin{array}{l}\text { Ofloxacin } \\
\text { Ciprofloxacin } \\
\text { Enrofloxacin } \\
\text { Ampicillin } \\
\text { Cefalexin } \\
\text { Azithromycin } \\
\text { Spiramycin } \\
\text { Lincomycin } \\
\text { Sulfamethoxazole } \\
\text { Sulfapyridine } \\
\text { Trimethoprim }\end{array}$ & UPLC-ESI & Waste water & Harrabi et al. [84] \\
\hline 29. & $\begin{array}{l}\text { Enrofloxacin } \\
\text { Ceftiofur } \\
\text { Ciprofloxacin } \\
\text { Sulfadiazine }\end{array}$ & HPLC-DAD & $\begin{array}{l}\text { Microbial culture } \\
\text { Solid and aqueous solution } \\
\text { Aqueous matrix }\end{array}$ & $\begin{array}{l}\text { Alexandrino et al. [5], Tappe et al. } \\
\text { [200] }\end{array}$ \\
\hline
\end{tabular}


Table 1 (continued)

\begin{tabular}{|c|c|c|c|c|}
\hline S. No. & Antibiotic & Detection & Matrix & References \\
\hline 30. & $\begin{array}{l}\text { Chlortetracycline } \\
\text { Monensin } \\
\text { Sulfamethazine } \\
\text { Tylosin } \\
\text { Virginiamycin } \\
\text { Sulfamethoxazole } \\
\text { Monensin } \\
\text { Salinomycin } \\
\text { Narasin }\end{array}$ & LC-MS & $\begin{array}{l}\text { Radish } \\
\text { Potato } \\
\text { Garlic } \\
\text { Corn } \\
\text { Spinach } \\
\text { Onion } \\
\text { Cabbage } \\
\text { Lettuce } \\
\text { Carrot } \\
\text { Microbial culture } \\
\text { Broiler litter \& soil microcosms }\end{array}$ & $\begin{array}{l}\text { Kang et al. [104], Ricken et al. [177], } \\
\text { Sun et al. [196] }\end{array}$ \\
\hline 31. & $\begin{array}{l}\text { Sulfamethoxazole } \\
\text { Sulfadiazine }\end{array}$ & GC-MS & $\begin{array}{l}\text { Liquid matrix } \\
\text { Aqueous matrix }\end{array}$ & Jiang et al. [100], Tappe et al. [200] \\
\hline 32. & Tetracycline & $\begin{array}{l}\text { Photoelectrocatalytic } \\
\text { ESI }\end{array}$ & Copper oxide nanorods & Eswar et al. [57] \\
\hline 33. & Sulfamethoxazole & $\begin{array}{l}\text { HPLC-MS/MS } \\
\text { IR }\end{array}$ & Aqueous matrix & Nguyen et al. [151] \\
\hline 34. & Sulfadiazine & LC-APCI-MS/MS & Aqueous matrix & Tappe et al. [200] \\
\hline
\end{tabular}

The half-life of antibiotics shows variations, depending on the type of matrix on which they adsorb/attach or interact. Ji et al. [99] showed Fe(III) activated persulfateassisted ciprofloxacin degradation up to $95 \%$ and sulfamethoxazole degradation up to 35\% [184] showed the gamma rays irradiated degradation of norfloxacin by HPLC and found out the intermediate and by-products by UPLCMS/MS-ESI. They also showed that $\mathrm{OH}$ in the presence of tert-butanol and 2-propanol played a critical role in the degradation of norfloxacin. The norfloxacin concentration in aqueous solution can be found out by $\mathrm{C}=\mathrm{Coe}-K_{\mathrm{d}}$ [130]. FQs are the fourth largest and most important antibiotics, frequently found in the surface water as an "emerging pollutant." Clinically is found that the antibiotics, administered to humans or livestock, maybe partially metabolized hence, can enter into agricultural runoff and wastewater. The detection of TET and metronidazole in Tunisia was below the limit of quantification (LOQ), it may be due to low antibiotic consumption [93], and there is only one study of Tunisia which showed the 14 aminoglycosides and amphenicols in wastewater, seawater, and pharmaceutical industry effluents [198]. Sulfonamides were detected in the range of $0.3-18 \mathrm{ng} / \mathrm{L}$ from the Netherlands' groundwater where livestock farming occurred. The 11 antibiotics, erythromycin, roxithromycin, tylosin, norfloxacin, ciprofloxacin, enrofloxacin, levofloxacin, sulfamethoxazole, sulfaquinolones, sulfamethazine, and OTC, were quantified in Brazilian soils, fertilized with the manure of animals. However, the rules and regulations are strict nowadays in European Union countries, but increased soil genes have been observed [187]. The sulfamethazine was found with a maximum concentration of $3.6 \mathrm{mg} / \mathrm{L}$ in the Californian dairy farm's groundwater
[212]. Hirsch et al. [87] were among the first research groups who detected the presence of antibiotics in the aquatic environment. Sacher et al. [179] carried out German groundwater monitoring and found the presence of sulfamethazine $(410 \mathrm{ng} / \mathrm{L})$. From the 1990 s until recent years, antibiotics are being detected at an alarming rate. Recently, antibiotic presence in surface water and groundwater was reported in a drinking water production site, in Germany, and among 26 antibiotics, eight were detected in surface water, while in groundwater, only trimethoprim was detected with concentrations between 5 and $12 \mathrm{ng} / \mathrm{L}$, among the 11 wells [28]. Another research group also carried out their work at the same region, in the high livestock production area and found sulfamethoxazole up to $950 \mathrm{ng} / \mathrm{L}$, and sulfadiazine and sulfamethazine below $12 \mathrm{ng} / \mathrm{L}$ among seven wells $[16,82]$.

Italian rivers were continually found to be contaminated by antibiotics. Antibiotics such as amoxicillin, ciprofloxacin, clarithromycin, erythromycin, lincomycin, metronidazole, oleandomycin, ofloxacin, OTC, sulfamethoxazole, sulfadiazine, sulfadimethoxine, sulfapyridine, spiramycin, tilmicosin, tylosin, vancomycin were detected. From there, we can imagine the level of resistance among the microbial community. Loos et al. [132] showed the detection frequency of ciprofloxacin and carbamazepine up to $90 \%$, and sulfamethoxazole up to $83 \%$ [139]. Krzeminski et al. [111] showed the detection limit of antibiotics, trimethoprim was detected up to $6000 \mathrm{ng} / \mathrm{L}$, clarithromycin up to $8000 \mathrm{ng} / \mathrm{L}$, azithromycin up to $6810 \mathrm{ng} / \mathrm{L}$, and metformin up to $>10,000 \mathrm{ng} / \mathrm{L}$. During the detection experiments, we may not be able to find out the exact concentration of antibiotics, because, during homogenization of plant tissues, antibiotics can be degraded in accelerated form 
because of the enzymes, stored in compartments. Plants may have the detoxification potential [26], and the antibiotics can be degraded in the plant cell vacuole [141].

Some antibiotics were reported to be present in an environment with the LOD as $0.05 \mathrm{mg} / \mathrm{mL}$ for ciprofloxacin and norfloxacin, and $0.01 \mathrm{mg} / \mathrm{mL}$ for enrofloxacin, while the LOQ was $0.01 \mathrm{mg} / \mathrm{mL}$ for ciprofloxacin and norfloxacin, and $0.05 \mathrm{mg} / \mathrm{mL}$ for enrofloxacin $[13,165]$. They also showed that photolysis of norfloxacin, enrofloxacin, and ciprofloxacin through solar radiation followed pseudofirst-order kinetics. The LOD of antibiotics were (Chlortetracycline $=0.10)$, (Monensin $=0.58)$, (Sulfamethazine $=0.10)$, (Tylosin $=0.02$ ), (viginiamycin $=0.09$ ) at $\mu \mathrm{g} / \mathrm{L}[104]$, while their LOQs were $0.13,1.0,0.27,0.14$ and 0.12 , respectively. The LOD and LOQ scenario showed the data variability, and it may depend on the environmental conditions and the sorption matrix hence, LOD cannot be universal for different matrices as each matrix has its potential to hold the antibiotic compound under the influence of chemical nature, free reacting groups, surrounding chemical niche, other chemically active compounds, and physical condition has driven forces.

\section{Remediation strategies by application of "omics" and molecular techniques}

Genomics provides revolutionary knowledge filling the gap between classical and modern microbiology. The field includes the analysis of biophysical techniques, e.g., chemical genomics, genotype and phenotype mapping, genome-scale library, pan-genome assemblies next-generation sequencing, quantitative PCRs, and bioinformatic tools [215].

The quantitative PCR is a technique to assess the efficiency of wastewater treatment plants for the removal of ARGs, and in 2016, Rafraf et al. 225 successfully observed ARGs in the influents and effluents of WWTPs. To enhance the efficiency of WWTPs, culturable antibiotic-resistant bacteria can be used. In Mycobacterium tuberculosis, the Tricarboxylic acetate (TCA) cycle enzyme, isocitrate lyase provides tolerance against the antibiotics, irrespective of their primary/known targets [148] which suggest the involvement of a specific metabolic pathway in combating the antibiotic stress by the bacteria. The activity of many antibiotics is dependent on the metabolic pathway of the biological system. However, the factors regarding their antibiotic activity are not elaborately discussed [14]. The action of antibiotics (ampicillin, norfloxacin, levofloxacin, gentamycin, daptomycin, and rifampin) is linked to the metabolic behavior of bacterial (E. coli and Staphylococcus aureus) machinery. Metabolism of bacteria (cellular respiration) may act downstream to antibiotics action (as bactericidal or bacteriostatic), while the accumulation of energy in the form of ATP, ADP, and AMP was seen and NAD \& NADH elevation was observed. These all were seen in the TCA cycle metabolism [131].

Belenky et al. [18] showed the induction of common metabolic pathways around the central carbon metabolism in E. coli in the stress of different antibiotics, e.g., ampicillin and kanamycin, and norfloxacin. This alteration of the TCA cycle leads to the production of oxidative stress, which results in DNA damage, nucleic acid oxidation, and double-stranded DNA breaks. Similarly, the TCA cycle's shunting to the glyoxylate cycle provides the tolerance to bacteria (Pseudomonas aeruginosa) against antibiotics and prevents the bacteria from using the sugar molecule/ metabolites of the glyoxylate cycle rather than TCA. Nucleotides and peptidoglycans are the building blocks of the bacterial cell, but their biosynthesis or up and down in the metabolism of central carbon and amino acids were seen under the stress of antibiotics (ciprofloxacin, erythromycin, fosfomycin, vancomycin, and ampicillin) (Dorries et al., [53]). Schelli et al. ([185], [186]) also proved that variation in the metabolic profile of bacteria under the different antibiotics' stress. Hence, it is proved that the metabolomic changes are dose-dependent, and specific metabolomic pathways can be triggered, depending on the level of stress. Recent technologies and enhanced knowledge smoothen our efficacy in detecting and identifying the specific targets and susceptibility of bacteria, e.g., nuclear magnetic resonance and mass spectrometry-based detection and advancement ([185], [186]; [89]). The intracellular and extracellular analysis of bacterial populations can be done by using fingerprinting and footprinting of cultures, and it will be very useful in the prediction of antibiotic targets and action [89], and even the data acquisition is also easy through systems biology. Through metabolomics, the mode of action and the targets of antibiotics begin to clear and helps in finding the particular enzyme or pathway at protein or DNA level [207]. In Gram-negative and Gram-positive bacterial (Staphylococcus aureus, Streptococcus pneumonia, E. coli, Pseudomonas aeruginosa) studies, the antimicrobial peptides (AMPs) along with systems biology tools, became a curious subject for investigation [110]. Through the systems biology approach, Kozlowska et al., [110] revealed the induction of bacterial response under the stress of specific AMPs. Genes and their enzymatic products influence metabolism; however, they are also somehow governed by non-enzymatic proteins [62]. The exact mechanism of the drug's action is not known. Ex post antibiotic growth, density-dependent changes, and persister cells hinder our understanding of drug-ligand chemical interaction and prevent the development of novel drugs to solve the problem of antibiotic resistance. The interventions of chemical reaction kinetics might 
help in understanding the chemical network. Brynildsen et al. [27] have developed a genome-level approach to enhance the ROS production in E. coli (in the presence of antibiotics) to understand the potential killing of bacteria. The OMICS approach can help us to find the targeted and non-targeted biology of the bacterial cell [168] through genomics. [61] have developed some measurements for the chemical genomic interaction investigations to maintain the growth and kinetics of the bacterial system. Interestingly, up to 200 percent increase in interactions were reported. This interaction is enhancing our experimental knowledge for the new perspectives and ideas in microbiology. [224] revealed the metabolic response (ammonium imbalance and synthesis of deoxythymidine 5-diphosphate (dTDP)-rhamnose) of E. coli through metabolomics against many different antibiotics (amoxicillin, ampicillin, chloramphenicol, kanamycin, norfloxacin, nalidixic acid, sulfamethizole, trimethoprim, and spectinomycin) perturbations. Metabolism of bacteria can change in response to environmental conditions and significantly helps the bacteria to adapt against the stress ([185], [186]). However, not much experimental evidence is reported until now [89]. The downstream metabolic pathways of bacteria are not very clear, and the metabolic changes in response to antibiotic stress can interfere with ROS production within the bacterial cell. E. coli being an organism whose metabolism is widely explored through metabolomics ([202]; [38]). [95] revealed the cross interaction between the TCA cycle and the peptidoglycan biosynthesis through -ketoglutarate influence in bacteria; Caulobacter crescentus. The flux balance analysis (FBA) is an increasingly useful and potentially good approach for modeling and predicting the more accurate prediction of the behavior of metabolomic systems, and they were used for the prediction of the genetic knockout with higher synergy levels and drug perturbations. Although metabolomics profiling reveals the cellular and genetic analytical possibilities to employ the drug-target (cellular metabolites) interactions, it also uncovers the antibiotic inhibiting and enhancing factors. This may lead to focusing on specific target-based treatment [147]. Jensen et al. [98] showed the stress-dependent response of bacteria through metabolomic profiling. They showed that the systematic and coordinated response under nutritional stress while the response under antibiotic stress was non-coordinated. However, the cost of fitness of genes under stress cannot be neglected, but transcriptional and functional coordination get disturbed under antibiotic stress. The microbial evaluation and the responsible metabolic interaction networks can be predicted through constraint-based models [23]. Based on the systemic and metabolic information, a novel remediation approach is diagrammatically described (Fig. 2) to combat antibiotic resistance and to overcome the antibiotic load from the environment. In Fig. 2, a proposed schematic diagram on the perspectives of antibiotics bioremediation is described. The chemistry of any compound provides us with its molecular formula, chemical structure, the atoms involved, bonding pattern, and bond energies. However, we need to create a database which consists of all the chemical information of antibiotics and should be connected to another database, having the information on bacterial strains. This will help us to select the antibiotic degrading bacteria by providing us with necessary biophysical and biochemical information. Then after switching on another database, which consists of all the proteins information of bacteria and their characterization, we would get the protein of our interest, to degrade the particular antibiotic, and for that, we will perform reverse transcription to get the exact DNA sequence through in silico approaches and clone it in the cloning vector to amplify the necessary protein. The amplified protein would extract out, concentrate and stored after lyophilization. Hence, on demand supply of potential proteins could be possible through these approaches and through field applications, can get the clear field site after remediation. By comparing the similar strains, we can exactly find out the potential degrader against the particular contamination. Hence, the genomic analysis through the proposed databases will be a milestone in the field of biodegradation.

\section{Initiatives and implementation of the policies of the twenty-first century}

The global report of surveillance of WHO has summarized the drug resistance among bacterial communities, while in May 2015, Federal Ministry of Health, Press Releases [59] issued their global plan to overcome antibiotic resistance, focused on food security and animal health. In addition to WHO initiatives and plans, European countries have also taken some decisions to combat antibiotic resistance, e.g., Germany launched Deutsche Antibiotika-Resistenz-Strategie (DART), to aim the minimization and prevention of antibiotic resistance [47]. Germany even amended their drug law in concern of high antibiotic use for growth promotion in livestock, in July 2014, and they are committed to keeping a record of the data of farm animals under antibiotic treatment [10] which shows their seriousness towards the global antibiotic resistance. Accelerated cases and emerging global problem of resistance leads to the WHO issue of "global plan of action to combat antibiotic resistance" and "global report of surveillance". The German government already amended its drug law in July 2014 to reduce antibiotic use in livestock [59]. While in developing countries like India, Brazil, etc., due to nonstrict or non-availability of exact policies for expired drug disposal, 


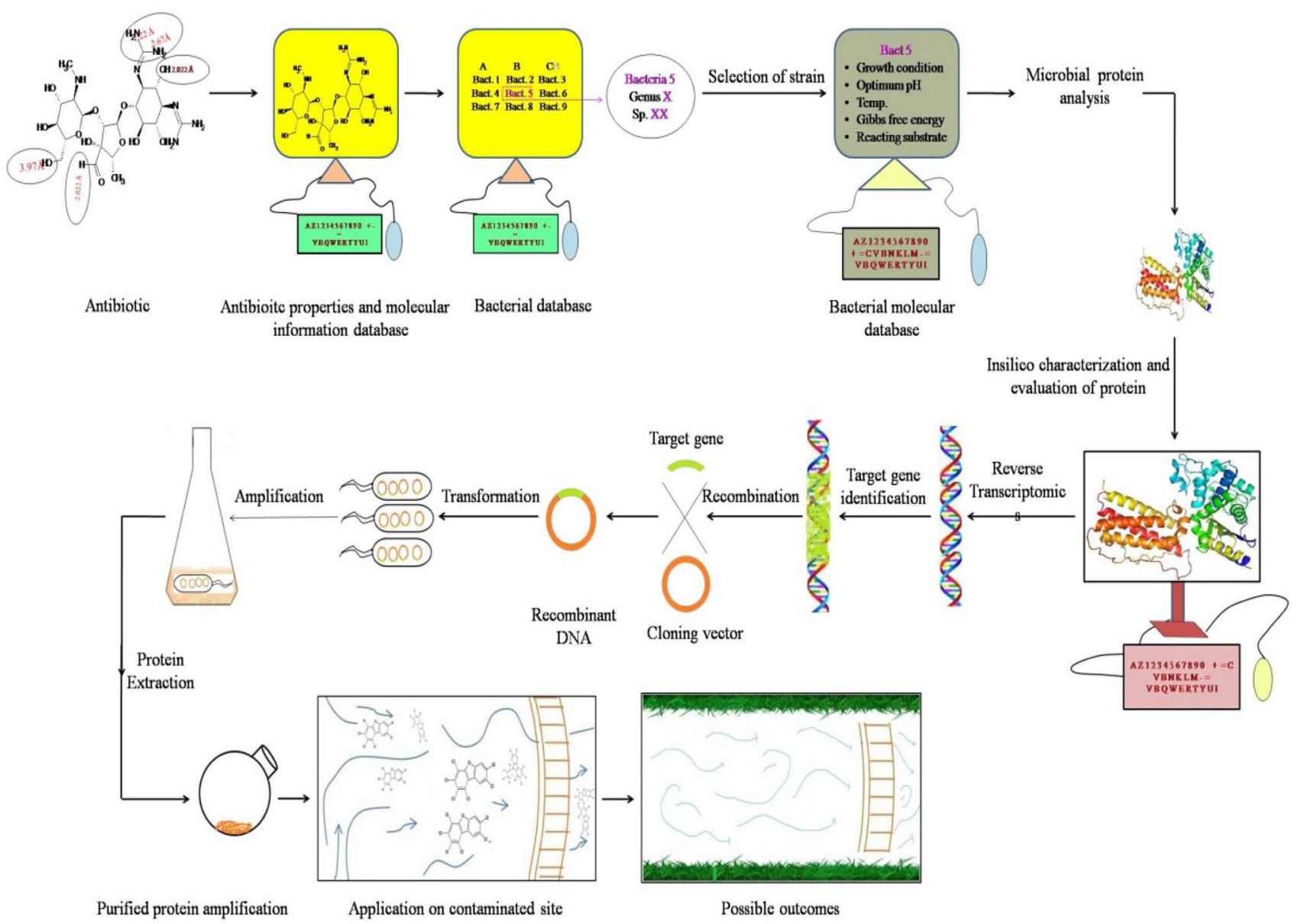

Fig. 2 Proposed schematic diagram on the perspectives of antibiotics bioremediation

antibiotics find their way to domestic or industrial waste. The public should know the consequences of antibiotic intakes, especially in developing countries, tackling the problem of antibiotic resistance. However, in European countries, Canada, and the United States, an annual antibiotic awareness day is declared, and it shows the strong commitment of developed countries to at least decrease the cases of resistance. Antibiotics were started to be given as feed additives for growth promotion of broilers, which have been shown to sacrifice their growth under Streptococcus faecium infection [63]. But due to increased and accelerated resistance, the optional enzymatic deployable strategies were adopted at some places as the alternatives of antibiotics. When phytases, proteases, and xylanase are added to poultry diets, they result in stimulating the biochemical pathways, which can lead to certain enzymatic reactions necessary for preventing the infections. The enzyme may be used as antimicrobial agents to hydrolyze the bacterial cell wall or weaken the glycocalyx and prevent bacterial infections. This is an emergent area for in-depth research in antimicrobial advancement [43].

\section{Conclusion and future perspectives}

Industrialization and modernization have likewise generated novel contaminants that could harm the environment. Pharmaceuticals are heavily used in medical therapeutics and veterinary, have been detected frequently in drinking water, soils, sediments, and surface water. Antibiotics are not fully metabolized by living beings and are recalcitrant to degradation, therefore cause adverse toxicity to living beings. The traditional water treatment plants are ineffective in the removal of the antibiotic. Hence, the risk to the environment and human health has increased and there is an urgent need for developing effective technologies to remove antibiotics from water. There is an urgent need for the improvement of WWTPSs and STPs to reduce the concentration of antibiotics discharged into the environment to reduce the toxicity. Therefore, it is recommended to use the combined treatment and tertiary treatment for increasing the removal efficiency of antibiotics. Although, antibiotics and resistance run simultaneously; hence, the spread of antibiotic resistance is an 
add-on of these countries to the whole world. European countries share their data about annual antibiotics consumption, the situation is worst in developing countries, e.g., India, where even actual consumption data are not available, and many folds lower production and consumption of antibiotics have been reported. It is also clear that the drugs, which were banned in Europe and America, are still sold in developing countries, even without the prescription of medical practitioners. Bacterial infections are the major cause of death in European countries, and the development of modern medicine and antibiotics should be needed for securing the future. Hence, we have to stop the antibiotic contamination either at the source stage (e.g., hospital effluent, poultry manure, veterinary effluents, etc.) or the sinking stage (e.g., wastewater) by their remediation through non-chemical remedies. Edible plants and crops are the major reservoir and carrier of antibiotic residues and may be used to remediate the contaminated site to secure the food web. Irradiated degradation of antibiotics from the hospital's effluents is suggested.

Acknowledgements Financial assistance provided by the NASF research grant (project entitled "Bioremediation of chemical contaminants and their complexes present in drainage water with high dynamic flux used for irrigation in urban and peri-urban agriculture"), sanction no. NASF/CA-6030/2017-18 is highly acknowledged. The author Kushneet Kaur Sodhi highly acknowledges the University Grant Commission (UGC), Government of India for providing the stipend and MK would like to thank Hindu college (DU) for providing the infrastructural facility and funds for the ongoing innovation project (SC/2019-2020/05 and SC/2019-2020/06). DKS particularly acknowledge the NASF (ICAR) for providing the funds for ongoing research, (NASF/CA-6030/2017-18).

\section{Compliance with ethical standards}

Conflict of interest None of the authors have any kind of financial or academic conflicts.

Human and animal rights This article does not contain any studies with human participants or animals performed by any of the authors.

Open Access This article is licensed under a Creative Commons Attribution 4.0 International License, which permits use, sharing, adaptation, distribution and reproduction in any medium or format, as long as you give appropriate credit to the original author(s) and the source, provide a link to the Creative Commons licence, and indicate if changes were made. The images or other third party material in this article are included in the article's Creative Commons licence, unless indicated otherwise in a credit line to the material. If material is not included in the article's Creative Commons licence and your intended use is not permitted by statutory regulation or exceeds the permitted use, you will need to obtain permission directly from the copyright holder. To view a copy of this licence, visit http://creativecommons .org/licenses/by/4.0/.

\section{References}

1. Ahmed MN, Porse A, Sommer MOA, Høiby N, Ciofu O (2018) Evolution of antibiotic resistance in biofilm and planktonic Pseudomonas aeruginosa populations exposed to subinhibitory levels of ciprofloxacin. Antimicrob Agents Chemother 62(8):e00320

2. Ahsan MA, Islam MT, Hernandez C, Kim H, Lin Y, Curry ML, Noveron JC (2018) Adsorptive removal of sulfamethoxazole and bisphenol a from contaminated water using functionalized carbonaceous material derived from tea leaves. J Environ Chem Eng 6(4):4215-4225

3. Ahsan MA, Santiago ARP, Rodriguez A, Maturano-Rojas V, Alvarado-Tenorio B, Bernal R, Noveron JC (2020) Biomassderived ultrathin carbon-shell coated iron nanoparticles as high-performance tri-functional HER, ORR and Fenton-like catalysts. J Clean Prod 275:124141

4. Alexander J, Bollmann A, Seitz W, Schwartz T (2015) Microbiological characterization of aquatic microbiomes targeting taxonomical marker genes and antibiotic resistance genes of opportunistic bacteria. Sci Total Environ 512:316-325

5. Alexandrino DA, Mucha AP, Almeida CMR, Gao W, Jia Z, Carvalho MF (2017) Biodegradation of the veterinary antibiotics enrofloxacin and ceftiofur and associated microbial community dynamics. Sci Total Environ 581:359-368

6. Al-Jassim N, Ansari MI, Harb M, Hong PY (2015) Removal of bacterial contaminants and antibiotic resistance genes by conventional wastewater treatment processes in Saudi Arabia: Is the treated wastewater safe to reuse for agricultural irrigation? Water Res 73:277-290

7. Amorim CL, Moreira IS, Maia AS, Tiritan ME, Castro PM (2014) Biodegradation of ofloxacin, norfloxacin, and ciprofloxacin as single and mixed substrates by Labrys portucalensis F11. Appl Microbiol Biotechnol 98(7):3181-3190

8. Annabi C, Fourcade F, Soutrel I, Geneste F, Floner D, Bellakhal $\mathrm{N}$, Amrane A (2016) Degradation of enoxacin antibiotic by the electro-Fenton process: optimization, biodegradability improvement and degradation mechanism. J Environ Manag 165:96-105

9. Aristilde L, Melis A, Sposito G (2010) Inhibition of photosynthesis by a fluoroquinolone antibiotic. Environ Sci Technol 44(4):1444-1450

10. Arzneimittelgesetz N (2005) Bundesgesetzblatt Teil I 73:3394-3469

11. Ayrapetyan M, Williams T, Oliver JD (2018) Relationship between the viable but nonculturable state and antibiotic persister cells. J Bacteriol 200(20):e00249

12. Hameed B, Din A, Ahmad A (2007) J Hazard Mater 141:819-825

13. Babić S, Periša M, Škorić I (2013) Photolytic degradation of norfloxacin, enrofloxacin and ciprofloxacin in various aqueous media. Chemosphere 91(11):1635-1642

14. Baek SH, Li AH, Sassetti CM (2011) Metabolic regulation of Mycobacterial growth and antibiotic sensitivity. PLoS Biol 9(5):e1001065

15. Baginska E, Haiß A, Kümmerer K (2015) Biodegradation screening of chemicals in an artificial matrix simulating the water-sediment interface. Chemosphere 119:1240-1246

16. Balzer F, Zühlke S, Hannappel S (2016) Antibiotics in groundwater under locations with high livestock density in Germany. Water Sci Technol Water Supply 16(5):1361-1369

17. Begic S, Worobec EA (2006) Regulation of Serratia marcescens ompF and ompC porin genes in response to osmotic stress, salicylate, temperature and $\mathrm{pH}$. Microbiology 152(2):485-491 
18. Belenky P, Jonathan DY, Porter CB, Cohen NR, Lobritz MA, Ferrante T, Collins JJ (2015) Bactericidal antibiotics induce toxic metabolic perturbations that lead to cellular damage. Cell Rep 13(5):968-980

19. Bergheim $M$, Gminski R, Spangenberg $B$, Debiak $M$, Bürkle $A$, Mersch-Sundermann V, Gieré R (2015) Antibiotics and sweeteners in the aquatic environment: biodegradability, formation of phototransformation products, and in vitro toxicity. Environ Sci Pollut Res 22(22):18017-18030

20. Birkigt J, Gilevska T, Ricken B, Richnow HH, Vione D, Corvini PFX, Cichocka D (2015) Carbon stable isotope fractionation of sulfamethoxazole during biodegradation by Microbacterium $\mathrm{sp}$. strain BR1 and upon direct photolysis. Environ Sci Technol 49(10):6029-6036

21. Blaak $H$, van Hoek $A H$, Hamidjaja $R A$, van der Plaats $R Q$, Kerkhof-de Heer L, de Roda HAM, Schets FM (2015) Distribution, numbers, and diversity of ESBL-producing $E$. coli in the poultry farm environment. PloS One 10(8):e0135402

22. Borah D, Yadav RNS (2015) Plasmid curing of a novel hydrocarbon degrading Bacillus cereus strain DRDU1 revealed its involvement in petroleum oil degradation. J Pet Environ Biotechnol 6(3): 1

23. Bordbar A, Monk JM, King ZA, Palsson BO (2014) Constraintbased models predict metabolic and associated cellular functions. Nat Rev Genet 15(2):107

24. Bouju H, Ricken B, Beffa T, Corvini PFX, Kolvenbach BA (2012) Isolation of bacterial strains capable of sulfamethoxazole mineralization from an acclimated membrane bioreactor. Appl Environ Microbiol 78(1):277-279

25. Boxall $A B$, Johnson $P$, Smith EJ, Sinclair CJ, Stutt E, Levy LS (2006) Uptake of veterinary medicines from soils into plants. J Agric Food Chem 54(6):2288-2297

26. Breuer J (2001) Aufnahme, Metabolismus und Bildung nichtextrahierbarer Rückstände aus 4-Nitrophenol in Soja und Weizen: Ein Vergleich verschiedener In-vitro-Systeme. Shaker

27. Brynildsen MP, Winkler JA, Spina CS, MacDonald IC, Collins JJ (2013) Potentiating antibacterial activity by predictably enhancing endogenous microbial ROS production. Nat Biotechnol 31(2):160

28. Burke V, Richter D, Greskowiak J, Mehrtens A, Schulz L, Massmann G (2016) Occurrence of antibiotics in surface and groundwater of a drinking water catchment area in Germany. Water Environ Res 88(7):652-659

29. Cabello FC, Godfrey HP, Tomova A, Ivanova L, Dölz H, Millanao A, Buschmann AH (2013) Antimicrobial use in aquaculture reexamined: its relevance to antimicrobial resistance and to animal and human health. Environ Microbiol 15:1917-1942

30. Camotti Bastos M, Rheinheimer dos Santos D, Aubertheau É, de Castro Lima JAM, Le Guet T, Caner L, Labanowski J (2018) Antibiotics and microbial resistance in Brazilian soils under manure application. Land Degrad Dev 29(8):2472-2484

31. Cardoza LA, Knapp CW, Larive CK, Belden JB, Lydy M, Graham DW (2005) Factors affecting the fate of ciprofloxacin in aquatic field systems. Water Air Soil Pollut 161(1-4):383-398

32. Carter LJ, Harris E, Williams M, Ryan JJ, Kookana RS, Boxall AB (2014) Fate and uptake of pharmaceuticals in soil-plant systems. J Agric Food Chem 62(4):816-825

33. Carvalho PN, Basto MCP, Almeida CMR, Brix H (2014) A review of plant-pharmaceutical interactions: from uptake and effects in crop plants to phytoremediation in constructed wetlands. Environ Sci Pollut Res 21(20):11729-11763

34. Casado J (2019) Towards industrial implementation of ElectroFenton and derived technologies for wastewater treatment: a review. J Environ Chem Eng 7(1):102823

35. CDC (2013) Antibiotic resistance threats in the united states. https://www.cdc.gov/drugresistance/biggest_threats.html
36. Çelik A, Casey E, Hasar H (2018) Degradation of oxytetracycline under autotrophic nitrifying conditions in a membrane aerated biofilm reactor and community fingerprinting. J Hazard Mater 356:26-33

37. Cetecioglu Z, Ince B, Azman S, Gokcek N, Coskun N, Ince O (2013) Determination of anaerobic and anoxic biodegradation capacity of sulfamethoxasole and the effects on mixed microbial culture. In: Biodegradation-engineering and technology. IntechOpen

38. Chandrasekaran S, Cokol-Cakmak M, Sahin N, Yilancioglu K, Kazan H, Collins JJ, Cokol M (2016) Chemogenomics and orthology-based design of antibiotic combination therapies. Mol Syst Biol 12(5):872

39. Chen HY, Liu YD, Dong B (2018) Biodegradation of tetracycline antibiotics in A/O moving-bed biofilm reactor systems. Bioprocess Biosyst Eng 41(1):47-56

40. Chen J, Liu YS, Zhang JN, Yang YQ, Hu LX, Yang YY, Ying GG (2017) Removal of antibiotics from piggery wastewater by biological aerated filter system: treatment efficiency and biodegradation kinetics. Biores Technol 238:70-77

41. Cheng W, Li J, Wu Y, Xu L, Su C, Qian Y, Chen H (2016) Behavior of antibiotics and antibiotic resistance genes in eco-agricultural system: a case study. J Hazard Mater 304:18-25

42. Chowdhury F, Langenkämper G, Grote M (2016) Studies on uptake and distribution of antibiotics in red cabbage. Journal für Verbraucherschutz und Lebensmittelsicherheit 11(1):61-69

43. Cowieson AJ, Kluenter AM (2019) Contribution of exogenous enzymes to potentiate the removal of antibiotic growth promoters in poultry production. Anim Feed Sci Technol 250:81-92

44. Cruz-Loya M, Kang TM, Lozano NA, Watanabe R, Tekin E, Damoiseaux R, Yeh PJ (2019) Stressor interaction networks suggest antibiotic resistance co-opted from stress responses to temperature. ISME J 13(1):12

45. Dai B, Liu Y, Jia J, Mei C (2010) Long-term antibiotics for the prevention of recurrent urinary tract infection in children: a systematic review and meta-analysis. Arch Dis Childh 95(7):499-508

46. Dalkmann P, Broszat $M$, Siebe $C$, Willaschek E, Sakinc T, Huebner J, Amelung W, Grohmann E, Siemens J (2012) Accumulation of pharmaceuticals, Enterococcus, and resistance genes in soils irrigated with wastewater for zero to 100 years in central Mexico. PLoS ONE 7:e45397

47. DART (2015) 2020 Antibiotika-Resistenzen beka"mpfen zum Wohl von Mensch und Tier. Bundesministerium fü $r$ Gesundheit (Hrsg), Berlin

48. DART Deutsche Antibiotika-Resistenzstrategie (2011) Bundesministerium für Gesundheit (Hrsg), Berlin

49. de Souza Santos LV, Teixeira DC, Jacob RS, Amaral MCSD, Lange LC (2014) Evaluation of the aerobic and anaerobic biodegradability of the antibiotic norfloxacin. Water Sci Technol 70(2):265-271

50. De D (2000) Plant cell vacuoles: an introduction. Csiro Publishing, London

51. Diago CAA, García-Unzueta MT, del Carmen Fariñas M, Amado JA (2016) Calcitriol-modulated human antibiotics: new pathophysiological aspects of vitamin D. Endocrinol Nutr 63(2):87-94

52. Dordio AV, Belo M, Teixeira DM, Carvalho AP, Dias CMB, Picó $Y$, Pinto AP (2011) Evaluation of carbamazepine uptake and metabolization by Typha spp., a plant with potential use in phytotreatment. Bioresour Technol 102(17):7827-7834

53. Dörries K, Schlueter R, Lalk M (2014) Impact of antibiotics with various target sites on the metabolome of Staphylococcus aureus. Antimicrob Agents Chemother 58(12):7151-7163

54. Durso LM, Cook KL (2014) Impacts of antibiotic use in agriculture: What are the benefits and risks? Curr Opin Microbiol 19:37-44 
55. ECDC (European Centre for Disease Prevention and Control), EFSA (European Food Safety Authority), and EMA (European Medicines Agency) (2017) ECDC/EFSA/EMA second joint report on the integrated analysis of the consumption of antimicrobial agents and occurrence of antimicrobial resistance in bacteria from humans and food-producing animals-Joint Interagency Antimicrobial Consumption and Resistance Analysis (JIACRA) Report. EFSA J 15(7):4872. https://doi.org/10.2903/j. efsa.2017.4872

56. EC-European Commission (2010) Commission regulation (EU) No 37/2010 of 22 December 2009 on pharmacologically active substances and their classification regarding maximum residue limits in foodstuffs of animal origin. Off J Eur Union L 15:1-72

57. Eswar NK, Singh SA, Madras G (2018) Photoconductive network structured copper oxide for simultaneous photoelectrocatalytic degradation of antibiotic (tetracycline) and bacteria ( $E$. coli). Chem Eng J 332:757-774

58. European Commission. Directorate-General for Energy (2003) European energy and transport trends to 2030: January 2003. European Communities

59. Federal Ministry of Health, Press Releases (2014) European Antibiotic Awareness Day 2014, Draft global action plan on antimicrobial resistance. http://www.who.int/mediacentre/ news/releases/2014/WHA-20140524/en/. Accessed on 25 May 2015

60. Figueroa RA, Leonard A, Mackay AA (2004) Modeling tetracycline antibiotic sorption to clays. Environ Sci Technol 38(2):476-483

61. French $S$, Mangat $C$, Bharat A, Côté JP, Mori H, Brown ED (2016) A robust platform for chemical genomics in bacterial systems. Mol Biol Cell 27(6):1015-1025

62. Fuhrer T, Zampieri M, Sévin DC, Sauer U, Zamboni N (2017) Genomewide landscape of gene-metabolome associations in Escherichia coli. Mol Syst Biol 13(1):907

63. Fuller R, Houghton SB, Coates ME (1983) The effect of dietary penicillin on the growth of gnotobiotic chickens monoassociated with Streptococcus faecium. Br Poult Sci 24(1):111-114

64. Gao L, Shi Y, Li W, Liu J, Cai Y (2015) Occurrence and distribution of antibiotics in urban soil in Beijing and Shanghai, China. Environ Sci Pollut Res 22(15):11360-11371

65. Gao P, He S, Huang S, Li K, Liu Z, Xue G, Sun W (2015) Impacts of coexisting antibiotics, antibacterial residues, and heavy metals on the occurrence of erythromycin resistance genes in urban wastewater. Appl Microbiol Biotechnol 99(9):3971-3980

66. García-Fernández A, Dionisi AM, Arena S, Iglesias-Torrens $Y$, Carattoli A, Luzzi I (2018) Human campylobacteriosis in Italy: emergence of multi-drug resistance to ciprofloxacin, tetracycline, and erythromycin. Front Microbiol 9:100

67. Gartiser S, Urich E, Alexy R, Kümmerer K (2007) Anaerobic inhibition and biodegradation of antibiotics in ISO test schemes. Chemosphere 66(10):1839-1848

68. Ge L, Chen J, Wei X, Zhang S, Qiao X, Cai X, Xie Q (2010) Aquatic photochemistry of fluoroquinolone antibiotics: kinetics, pathways, and multivariate effects of main water constituents. Environ Sci Technol 44(7):2400-2405

69. Ge L, Dong Q, Halsall C, Chen C-EL, Li J, Wang D, Zhang P, Yao Z (2018) Aqueous multivariate phototransformation kinetics of dissociated tetracycline: implications for the photochemical fate in surface waters. Environ Sci Pollut Res 25(16):15726-15732

70. Ge L, Halsall C, Chen CE, Zhang P, Dong Q, Yao Z (2018) Exploring the aquatic photodegradation of two ionizable fluoroquinolone antibiotics-Gatifloxacin and balofloxacin: degradation kinetics, photobyproducts and risk to the aquatic environment. Sci Total Environ 633:1192-1197
71. Ge L, Na G, Zhang S, Li K, Zhang P, Ren H, Yao Z (2015) New insights into the aquatic photochemistry of fluoroquinolone antibiotics: direct photodegradation, hydroxyl-radical oxidation, and antibacterial activity changes. Sci Total Environ 527:12-17

72. Girardi C, Greve J, Lamshöft M, Fetzer I, Miltner A, Schäffer A, Kästner M (2011) Biodegradation of ciprofloxacin in water and soil and its effects on the microbial communities. J Hazard Mater 198:22-30

73. Goldstein M, Shenker M, Chefetz B (2014) Insights into the uptake processes of wastewater-borne pharmaceuticals by vegetables. Environ Sci Technol 48(10):5593-5600

74. Grenni P, Ancona V, Caracciolo AB (2018) Ecological effects of antibiotics on natural ecosystems: a review. Microchem J 136:25-39

75. Grote M, Meric DH, Langenka"mper G, Hayen H, Betsche T, Freitag M (2009) Untersuchungen zum Transfer pharmakologisch

76. Grote M, Schwake-Anduschus C, Michel R, Heyser W, Hayen $H$, Langenka"mper G, Betsche T, Freitag M (2007b) Aufnahmeund Transport von Tierarzneistoffen in Nutzpflanzen; In: Münchener Beiträge zur Abwasser-, Fischerei- und Flussbiologie, Band 58, Vortra" ge der 58. Fachtagung "Tierarzneimittel in der Umwelt, Bayrisches Landesamt für Umwelt (ed), Oldenburg Industrieverlag $\mathrm{GmbH}$

77. Grote M, Schwake-Anduschus C, Michel R, Stevens H, Heyser W, Langenkämper G, Betsche T, Freitag M (2007) Incorporation of veterinary antibiotics into crops from manured soil. Landbauforschung Völkenrode 57:25-32

78. Grote M, Vockel A, Schwarze A, Mehlich A, Freitag M (2006) Antibiotika-Aufnahme von Nutzpflanzen aus Gu“llegedüngten Bo"den-Ergebnisse eines Modellversuchs. J Verbr Lebensm 1:38-50

79. Grote M, Schwake-Anduschus C, Michel R, Stevens H, Heyser W, Langenkamper G, Freitag M (2007) Incorporation of veterinary antibiotics into crops from manured soil. Landbauforschung Volkenrode 57(1):25

80. Grujic S, Vasiljevic T, Lausevic M, Ast T (2008) Study on the formation of an amoxicillin adduct with methanol using electrospray ion trap tandem mass spectrometry. Rapid Commun Mass Spectrom 22(1):67-74

81. Gurr CJ, Reinhard M (2006) Harnessing natural attenuation of pharmaceuticals and hormones in rivers

82. Hannappel S, Balzer F, Groeneweg J, Zuehlke S, Schulz D (2014) Incidence of veterinary drugs in near-surface groundwater below sites with high livestock density in Germany. Hydrol Wasserbewirtsch 58(4):208-220

83. Hao H, Yuan Z, Shen Z, Han J, Sahin O, Liu P, Zhang Q (2013) Mutational and transcriptomic changes involved in the development of macrolide resistance in Campylobacter jejuni. Antimicrob Agents Chemother 57(3):1369-1378

84. Harrabi M, Della Giustina SV, Aloulou F, Rodriguez-Mozaz S, Barceló D, Elleuch B (2018) Analysis of multiclass antibiotic residues in urban wastewater in Tunisia. Environ Nanotechnol Monitor Manag 10:163-170

85. He K, Blaney L (2015) Systematic optimization of an SPE with HPLC-FLD method for fluoroquinolone detection in wastewater. J Hazard Mater 282:96-105

86. Herzog B, Lemmer H, Horn H, Müller E (2013) Characterization of pure cultures isolated from sulfamethoxazole-acclimated activated sludge with respect to taxonomic identification and sulfamethoxazole biodegradation potential. BMC Microbiol 13(1):276

87. Hirsch R, Ternes T, Haberer K, Kratz KL (1999) Occurrence of antibiotics in the aquatic environment. Sci Total Environ 225(1-2):109-118 
88. Ho YB, Zakaria MP, Latif PA, Saari N (2013) Degradation of veterinary antibiotics and hormone during broiler manure composting. Biores Technol 131:476-484

89. Hoerr V, Duggan GE, Zbytnuik L, Poon KK, Große C, Neugebauer U, Vogel HJ (2016) Characterization and prediction of the mechanism of action of antibiotics through NMR metabolomics. BMC Microbiol 16(1):82

90. Hou J, Wan W, Mao D, Wang C, Mu Q, Qin S, Luo Y (2015) Occurrence and distribution of sulfonamides, tetracyclines, quinolones, macrolides, and nitrofurans in livestock manure and amended soils of Northern China. Environ Sci Pollut Res 22(6):4545-4554

91. Huang D, Wang X, Zhang C, Zeng G, Peng Z, Zhou J, Qin X (2017) Sorptive removal of ionizable antibiotic sulfamethazine from aqueous solution by graphene oxide-coated biochar nanocomposites: influencing factors and mechanism. Chemosphere 186:414-421

92. Huang S, Gan N, Li T, Zhou Y, Cao Y, Dong Y (2018) Electrochemical aptasensor for multi-antibiotics detection based on endonuclease and exonuclease assisted dual recycling amplification strategy. Talanta 179:28-36

93. INC (Institut National de la Consommation) (2016) Rapport scientifique de la journée mondiale 2016 des droits des consommateurs «Aliments sans ATB»ou«Du mésusage des ATB»

94. lovine NM (2013) Resistance mechanisms in Campylobacter jejuni. Virulence 4:230-240

95. Irnov I, Wang Z, Jannetty ND, Bustamante JA, Rhee KY, JacobsWagner C (2017) Crosstalk between the tricarboxylic acid cycle and peptidoglycan synthesis in Caulobacter crescentus through the homeostatic control of a-ketoglutarate. PLoS Genet 13(8):e1006978

96. Islam MT, Saenz-Arana R, Hernandez C, Guinto T, Ahsan MA, Kim H, Noveron JC (2018) Adsorption of methylene blue and tetracycline onto biomass-based material prepared by sulfuric acid reflux. RSC Adv 8(57):32545-32557

97. Jensen Anwar, Shaque U, Waheed-uz-Zaman, Salman M, Hussain Z, Saleem M, Shahid N, Mahboob S, Ghafoor S, Akram M, Rehman R (2010) Green Chem Lett Rev 3:239-243

98. Jensen PA, Zhu Z, van Opijnen T (2017) Antibiotics disrupt coordination between transcriptional and phenotypic stress responses in pathogenic bacteria. Cell Rep 20(7):1705-1716

99. Ji Y, Ferronato C, Salvador A, Yang X, Chovelon JM (2014) Degradation of ciprofloxacin and sulfamethoxazole by ferrous-activated persulfate: implications for remediation of groundwater contaminated by antibiotics. Sci Total Environ 472:800-808

100. Jiang B, Li A, Cui D, Cai R, Ma F, Wang Y (2014) Biodegradation and metabolic pathway of sulfamethoxazole by Pseudomonas psychrophila HA-4, a newly isolated cold-adapted sulfamethoxazole-degrading bacterium. Appl Microbiol Biotechnol 98(10):4671-4681

101. Jjemba PK (2002) The potential impact of veterinary and human therapeutic agents in manure and biosolids on plants grown on arable land: a review. Agr Ecosyst Environ 93(1-3):267-278

102. Saravanan KR, Kalaiselvi N (2015) Carbon 81:43-53

103. Kaakoush NO, Castaño-Rodríguez N, Mitchell HM, Man SM (2015) Global epidemiology of Campylobacter infection. Clin Microbiol Rev 28(3):687-720

104. Kang DH, Gupta S, Rosen C, Fritz V, Singh A, Chander Y, Rohwer C (2013) Antibiotic uptake by vegetable crops from manureapplied soils. J Agric Food Chem 61(42):9992-10001

105. Kay P, Blackwell PA, Boxall AB (2004) Fate of veterinary antibiotics in a macroporous tile drained clay soil. Environ Toxicol Chem 23(5):1136-1144

106. Kinrys G, Gold AK, Worthington JJ, Nierenberg AA (2018) Medication disposal practices: Increasing patient and clinician education on safe methods. J Int Med Res 46(3):927-939
107. Kivits T, Broers HP, Beeltje H, van Vliet M, Griffioen J (2018) Presence and fate of veterinary antibiotics in age-dated groundwater in areas with intensive livestock farming. Environ Pollut 241:988-998

108. Kling A, Chatelle C, Armbrecht L, Qelibari E, Kieninger J, Dincer C, Urban G (2016) Multianalyte antibiotic detection on an electrochemical microfluidic platform. Anal Chem 88(20):10036-10043

109. Knapp CW, McCluskey SM, Singh BK, Campbell CD, Hudson G, Graham DW (2011) Antibiotic resistance gene abundances correlate with metal and geochemical conditions in archived Scottish soils. PLoS ONE 6(11):e27300

110. Kozlowska J, Vermeer LS, Rogers GB, Rehnnuma N, Amos SBT, Koller G, Mason AJ (2014) Combined systems approaches reveal highly plastic responses to antimicrobial peptide challenge in E. coli. PLoS Pathog 10(5):e1004104

111. Krzeminski $P$, Tomei MC, Karaolia P, Langenhoff A, Almeida CMR, Felis E, Gritten F, Andersen HR, Fernandes T, Manaia CM, Rizzo L, Fatta-Kassinos D (2019) Performance of secondary wastewater treatment methods for the removal of contaminants of emerging concern implicated in crop uptake and antibiotic resistance spread: a review. Sci Total Environ 648:1052-1081

112. Kumar K, Gupta SC, Baidoo SK, Chander Y, Rosen CJ (2005) Antibiotic uptake by plants from soil fertilized with animal manure. J Environ Qual 34:2082-2085

113. Kumar M, Jaiswal S, Sodhi KK, Shree P, Singh DK, Agrawal PK, Shukla P (2019) Antibiotics bioremediation: perspectives on its ecotoxicity and resistance. Environ Int 124:448-461

114. Kümmerer K (2003) Significance of antibiotics in the environment. J Antimicrob Chemother 52(1):5-7

115. Kümmerer K, Al-Ahmad A, Mersch-Sundermann V (2000) Biodegradability of some antibiotics, elimination of the genotoxicity and affection of wastewater bacteria in a simple test. Chemosphere 40(7):701-710

116. Lan L, Yao Y, Ping J, Ying Y (2017) Recent advances in nanomaterial-based biosensors for antibiotics detection. Biosens Bioelectronics, 91:504-514

117. Larcher S, Yargeau V (2012) Biodegradation of sulfamethoxazole: current knowledge and perspectives. Appl Microbiol Biotechnol 96(2):309-318

118. Lee MD, Maurer JJ (2000) The genetic basis for emerging antibiotic resistance in veterinary pathogens. Ann N Y Acad Sci 916(1):643-645

119. Lei X, Lu J, Liu Z, Tong Y, Li S (2015) Concentration and distribution of antibiotics in water-sediment system of Bosten Lake, Xinjiang. Environ Sci Pollut Res 22(3):1670-1678

120. Lertpaitoonpan W, Ong SK, Moorman TB (2009) Effect of organic carbon and $\mathrm{pH}$ on soil sorption of sulfamethazine. Chemosphere 76(4):558-564

121. Leung HW, Minh TB, Murphy MB, Lam JC, So MK, Martin M, Richardson BJ (2012) Distribution, fate and risk assessment of antibiotics in sewage treatment plants in Hong Kong, South China. Environ Int 42:1-9

122. Levy SB (1992) Active efflux mechanisms for antimicrobial resistance. Antimicrob Agents Chemother 36(4):695

123. Li B, Zhang $T$ (2010) Biodegradation and adsorption of antibiotics in the activated sludge process. Environ Sci Technol 44(9):3468-3473

124. Liao X, Li B, Zou R, Dai Y, Xie S, Yuan B (2016) Biodegradation of antibiotic ciprofloxacin: pathways, influential factors, and bacterial community structure. Environ Sci Pollut Res 23(8):7911-7918

125. Liao X, Li B, Zou R, Xie S, Yuan B (2016) Antibiotic sulfanilamide biodegradation by acclimated microbial populations. Appl Microbiol Biotechnol 100(5):2439-2447 
126. Lin YC, Hsiao KW, Lin AYC (2018) Photolytic degradation of ciprofloxacin in solid and aqueous environments: kinetics, phototransformation pathways, and byproducts. Environ Sci Pollut Res 25(3):2303-2312

127. Liu MK, Liu YY, Bao DD, Zhu G, Yang GH, Geng JF, Li HT (2017) Effective removal of tetracycline antibiotics from water using hybrid carbon membranes. Sci Rep 7:43717

128. Liu S, Zhao H, Lehmler HJ, Cai X, Chen J (2017) Antibiotic pollution in marine food webs in Laizhou Bay, North China: trophodynamics and human exposure implication. Environ Sci Technol 51(4):2392-2400

129. Liu X, Hu Y, Pai PJ, Chen D, Lam H (2014) Label-free quantitative proteomics analysis of antibiotic response in Staphylococcus aureus to oxacillin. J Proteome Res 13(3):1223-1233

130. Liu Y, Zhang J, Zhao L, Li Y, Dai Y, Xie S (2015) Distribution of sediment ammonia-oxidizing microorganisms in plateau freshwater lakes. Appl Microbiol Biotechnol 99(10):4435-4444

131. Lobritz MA, Belenky P, Porter CB, Gutierrez A, Yang JH, Schwarz EG, Collins JJ (2015) Antibiotic efficacy is linked to bacterial cellular respiration. Proc Natl Acad Sci 112(27):8173-8180

132. Loos R, Carvalho R, António DC, Comero S, Locoro G, Tavazzi $S$, Jarosova B (2013) EU-wide monitoring survey on emerging polar organic contaminants in wastewater treatment plant effluents. Water Res 47(17):6475-6487

133. Lopes TR, Costa IL Jr, Periotto F, Pletsch AL (2016) Antibiotic resistance in $E$. coli isolated in effluent from a wastewater treatment plant and sediments in receiver body. Int J River Basin Manag 14(4):441-445

134. Lützhøft $\mathrm{HCH}$, Vaes WHJ, Freidig AP, Halling-Sørensen $B$, Hermens JLM (2000) 1-Octanol/water distribution coefficient of oxolinic acid: influence of $\mathrm{pH}$ and its relation to the interaction with dissolved organic carbon. Chemosphere 40(7):711-714

135. Maia PP, da Silva EC, Rath S, Reyes FGR (2009) Residue content of oxytetracycline applied on tomatoes grown in open field and greenhouse. Food Control 20(1):11

136. Manaia CM, Macedo G, Fatta-Kassinos D, Nunes OC (2016) Antibiotic resistance in urban aquatic environments: can it be controlled? Appl Microbiol Biotechnol 100(4):1543-1557

137. Mao D, Yu S, Rysz M, Luo Y, Yang F, Li F, Alvarez PJJ (2015) Prevalence and proliferation of antibiotic resistance genes in two municipal wastewater treatment plants. Water Res 85:458-466

138. Mao F, Liu X, Wu K, Zhou C, Si Y (2018) Biodegradation of sulfonamides by Shewanella oneidensis MR-1 and Shewanella sp. strain MR-4. Biodegradation 29(2):129-140

139. Margot J, Kienle C, Magnet A, Weil M, Rossi L, De Alencastro LF, Barry DA (2013) Treatment of micropollutants in municipal wastewater: ozone or powdered activated carbon? Sci Total Environ 461:480-498

140. Marsoni M, De Mattia F, Labra M, Bruno A, Bracale M, Vannini C (2014) Uptake and effects of a mixture of widely used therapeutic drugs in Eruca sativa L. and Zea mays L. plants. Ecotoxicol Environ Saf 108:52-57

141. Marty F (1999) Plant vacuoles. Plant Cell 11(4):587-599

142. Massé D, Saady N, Gilbert Y (2014) Potential of biological processes to eliminate antibiotics in livestock manure: an overview. Animals 4(2):146-163

143. McEachran AD, Blackwell BR, Hanson JD, Wooten KJ, Mayer GD, Cox SB, Smith PN (2015) Antibiotics, bacteria, and antibiotic resistance genes: aerial transport from cattle feed yards via particulate matter. Environ Health Perspect 123(4):337-343

SN Applied Sciences

APRINGER NATURE journa
144. McKinney CW, Dungan RS, Moore A, Leytem AB (2018) Occurrence and abundance of antibiotic resistance genes in agricultural soil receiving dairy manure. FEMS Microbiol Ecol 94(3):10

145. Meng XZ, Venkatesan AK, Ni YL, Steele JC, Wu LL, Bignert A, Halden RU (2016) Organic contaminants in Chinese sewage sludge: a meta-analysis of the literature of the past 30 years. Environ Sci Technol 50(11):5454-5466

146. Miran W, Jang J, Nawaz M, Shahzad A, Lee DS (2018) Biodegradation of the sulfonamide antibiotic sulfamethoxazole by sulfamethoxazole acclimatized cultures in microbial fuel cells. Sci Total Environ 627:1058-1065

147. Montezano D, Meek L, Gupta R, Bermudez LE, Bermudez JC (2015) Flux balance analysis with objective function defined by proteomics data-metabolism of Mycobacterium tuberculosis exposed to mefloquine. PLoS ONE 10(7):e0134014

148. Nandakumar M, Nathan C, Rhee KY (2014) Isocitrate lyase mediates broad antibiotic tolerance in Mycobacterium tuberculosis. Nat Commun 5:4306

149. Naylor NR, Atun R, Zhu N, Kulasabanathan K, Silva S, Chatterjee A, Robotham JV (2018) Estimating the burden of antimicrobial resistance: a systematic literature review. Antimicrob Resistance Infection Control 7(1):58

150. Nguyen LH, Chong NM (2015) Conditions for supplemental biogenic substrates to enhance activated sludge degradation of xenobiotic. Appl Microbiol Biotechnol 99(19):8247-8257

151. Nguyen PY, Carvalho G, Reis AC, Nunes OC, Reis MAM, Oehmen A (2017) Impact of biogenic substrates on sulfamethoxazole biodegradation kinetics by Achromobacter denitrificans strain PR1. Biodegradation 28(2-3):205-217

152. Niu XZ, Busetti F, Langsa M, Croué JP (2016) Roles of singlet oxygen and dissolved organic matter in self-sensitized photooxidation of antibiotic norfloxacin under sunlight irradiation. Water Res 106:214-222

153. Nõlvak H, Truu M, Tiirik K, Oopkaup K, Sildvee T, Kaasik A, Truu $J$ (2013) Dynamics of antibiotic resistance genes and their relationships with system treatment efficiency in a horizontal subsurface flow constructed wetland. Sci Total Environ 461:636-644

154. Nowara A, Burhenne J, Spiteller M (1997) Binding of fluoroquinolone carboxylic acid derivatives to clay minerals. J Agric Food Chem 45(4):1459-1463

155. Osińska A, Korzeniewska E, Harnisz M, Niestępski S (2017) The prevalence and characterization of antibiotic-resistant and virulent Escherichia coli strains in the municipal wastewater system and their environmental fate. Sci Total Environ 577:367-375

156. Östman $M$, Lindberg RH, Fick J, Björn E, Tysklind M (2017) Screening of biocides, metals and antibiotics in Swedish sewage sludge and wastewater. Water Res 115:318-328

157. Ou D, Chen B, Bai R, Song P, Lin H (2015) Contamination of sulfonamide antibiotics and sulfamethazine-resistant bacteria in the downstream and estuarine areas of Jiulong River in Southeast China. Environ Sci Pollut Res 22(16):12104-12113

158. Pachepsky Y, Morrow J, Guber A, Shelton D, Rowland R, Davies $G$ (2012) Effect of biofilm in irrigation pipes on microbial quality of irrigation water. Lett Appl Microbiol 54(3):217-224

159. Pailan S, Gupta D, Apte S, Krishnamurthi S, Saha P (2015) Degradation of organophosphate insecticide by a novel Bacillus aryabhattai strain SanPS1, isolated from soil of agricultural field in Burdwan, West Bengal, India. Int Biodeterior Biodegradation 103:191-195

160. Pan LJ, Li CX, Yu GW, Wang Y (2017) Biodegradation of sulfamethazine by an isolated thermophile-Geobacillus sp. S-07. World J Microbiol Biotechnol 33(5):85

161. Papageorgiou M, Kosma C, Lambropoulou D (2016) Seasonal occurrence, removal, mass loading and environmental risk 
assessment of 55 pharmaceuticals and personal care products in a municipal wastewater treatment plant in Central Greece. Sci Total Environ 543:547-569

162. Park H, Choung YK (2013) Evaluation of the biodegradation feasibility of antibiotics by three bacteria involving glutathione S-transferases. J Environ Eng Sci 8(5):550-555

163. Paulsen IT, Park JH, Choi PS, Saier MH Jr (1997) A family of gramnegative bacterial outer membrane factors that function in the export of proteins, carbohydrates, drugs and heavy metals from gram-negative bacteria. FEMS Microbiol Lett 156(1):1-8

164. Pawar MK, Tayade KC, Sahoo SK, Mahulikar PP, Kuwar AS, Chaudhari BL (2016) Selective ciprofloxacin antibiotic detection by fluorescent siderophore pyoverdin. Biosens Bioelectron 81:274-279

165. Peng J, Liu L, Kuang H, Cui G, Xu C (2017) Development of an icELISA and immunochromatographic strip for detection of norfloxacin and its analogs in milk. Food Agric Immunol 28(2):288-298

166. Peng J, Wang Y, Liu L, Kuang H, Li A, Xu C (2016) Multiplex lateral flow immunoassay for five antibiotics detection based on gold nanoparticle aggregations. RSC Adv 6(10):7798-7805

167. Pereira JH, Reis AC, Queirós D, Nunes OC, Borges MT, Vilar VJ, Boaventura RA (2013) Insights into solar $\mathrm{TiO}_{2}$-assisted photocatalytic oxidation of two antibiotics employed in aquatic animal production, oxolinic acid and oxytetracycline. Sci Total Environ 463:274-283

168. Peters JM, Colavin A, Shi H, Czarny TL, Larson MH, Wong S, Shiver AL (2016) A comprehensive, CRISPR-based functional analysis of essential genes in bacteria. Cell 165(6):1493-1506

169. Ponte S (2002) Thelatte revolution'? Regulation, markets, and consumption in the global coffee chain. World Dev 30(7):1099-1122

170. Polesel F, Andersen HR, Trapp S, Plosz BG (2016) Removal of antibiotics in biological wastewater treatment systems. A critical assessment using the activated sludge modeling framework for xenobiotics (ASM-X). Environ Sci Technol 50(19):10316-10334

171. Porras J, Bedoya C, Silva-Agredo J, Santamaría A, Fernández JJ, Torres-Palma RA (2016) Role of humic substances in the degradation pathways and residual antibacterial activity during the photodecomposition of the antibiotic ciprofloxacin in water. Water Res 94:1-9

172. Porubcan LS, Serna CJ, White JL, Hem SL (1978) Mechanism of adsorption of clindamycin and tetracycline by montmorillonite. J Pharm Sci 67(8):1081-1087

173. Qiao M, Ying GG, Singer AC, Zhu YG (2018) Review of antibiotic resistance in China and its environment. Environ Int 110:160-172

174. Qu J, Xu Y, Ai GM, Liu Y, Liu ZP (2015) Novel Chryseobacterium sp. PYR2 degrades various organochlorine pesticides (OCPs) and achieves enhancing removal and complete degradation of DDT in highly contaminated soil. J Environ Manag 161:350-357

175. Raats PAC (1981) Residence times of water and solutes within and below the root zone. Agric Water Manag 4(1-3):63-82

176. Reyns T, De Boever S, De Baere S, De Backer P, Croubels $S$ (2007) Tissue depletion of amoxicillin and its major metabolites in pigs: influence of the administration route and the simultaneous dosage of clavulanic acid. J Agric Food Chem 56(2):448-454

177. Ricken B, Corvini PF, Cichocka D, Parisi M, Lenz M, Wyss D, Kohler HPE (2013) Ipso-hydroxylation and subsequent fragmentation: a novel microbial strategy to eliminate sulfonamide antibiotics. Appl Environ Microbiol 79(18):5550-5558

178. Rodriguez-Mozaz S, Chamorro S, Marti E, Huerta B, Gros M, Sànchez-Melsió A, Balcázar JL (2015) Occurrence of antibiotics and antibiotic resistance genes in hospital and urban wastewaters and their impact on the receiving river. Water Res 69:234-242

179. Sacher F, Lange FT, Brauch HJ, Blankenhorn I (2001) Pharmaceuticals in groundwaters: analytical methods and results of a monitoring program in Baden-Württemberg, Germany. J Chromatogr A 938(1-2):199-210

180. Sági G, Bezsenyi A, Kovács K, Klátyik S, Darvas B, Székács $A$, Mohácsi-Farkas C, Takács E, Wojnárovits L (2018) Radiolysis of sulfonamide antibiotics in aqueous solution: degradation efficiency and assessment of antibacterial activity, toxicity and biodegradability of products. Sci Total Environ 622:1009-1015

181. San MA (2018) Evolution of plasmid-mediated antibiotic resistance in the clinical context. Trends Microbiol 5:23

182. Santos $L$, Ramos F (2016) Analytical strategies for the detection and quantification of antibiotic residues in aquaculture fishes: a review. Trends Food Sci Technol 52:16-30

183. Sassman SA, Lee LS (2005) Sorption of three tetracyclines by several soils: assessing the role of $\mathrm{pH}$ and cation exchange. Environ Sci Technol 39(19):7452-7459

184. Sayed M, Khan JA, Shah LA, Shah NS, Khan HM, Rehman F, Khan AM (2016) Degradation of quinolone antibiotic, norfloxacin, in aqueous solution using gamma-ray irradiation. Environ Sci Pollut Res 23(13):13155-13168

185. Schelli K, Rutowski J, Roubidoux J, Zhu J (2017) Staphylococcus aureus methicillin resistance detected by HPLC-MS/MS targeted metabolic profiling. J Chromatogr B 1047:124-130

186. Schelli K, Zhong F, Zhu J (2017) Comparative metabolomics revealing Staphylococcus aureus metabolic response to different antibiotics. Microb Biotechnol 10(6):1764-1774

187. Schmitt $H$, Blaak $H$, Kemper $M$, van Passel MW, Hierink F, Van Leuken J, de Man H (2017) Bronnen van antibioticaresistentie in het milieu en mogelijke maatregelen

188. Selvi A, Das D, Das N (2015) Potentiality of yeast Candida sp. SMN04 for degradation of cefdinir, a cephalosporin antibiotic: kinetics, enzyme analysis and biodegradation pathway. Environ Technol 36(24):3112-3124

189. Shade A, Klimowicz AK, Spear RN, Linske M, Donato JJ, Hogan CS, McManus PS, Handelsman J (2013) Streptomycin application has no detectable effect on bacterial community structure in apple orchard soil. Appl Environ Microbiol 79:6617-6625

190. Sharma VK, Johnson N, Cizmas L, McDonald TJ, Kim H (2016) A review of the influence of treatment strategies on antibiotic resistant bacteria and antibiotic resistance genes. Chemosphere 150:702-714

191. Sodhi KK, Kumar M, Balan B, Dhaulaniya AS, Singh DK (2019) Isolation and characterization of amoxicillin-resistant bacteria and amoxicillin-induced alteration in its protein profiling and RNA yield. Archiv Microbiol 3:1-8

192. Solís-González CJ, Loza-Tavera H (2019) Alicycliphilus: current knowledge and potential for bioremediation of xenobiotics. J Appl Microbiol 2:16

193. Sturini M, Speltini A, Maraschi F, Pretali L, Ferri EN, Profumo A (2015) Sunlight-induced degradation of fluoroquinolones in wastewater effluent: Photoproducts identification and toxicity. Chemosphere 134:313-318

194. Sturini M, Speltini A, Maraschi F, Rivagli E, Profumo A (2010) Solvent-free microwave-assisted extraction of fluoroquinolones from soil and liquid chromatography-fluorescence determination. J Chromatogr A 1217(47):7316-7322

195. Sun J, Luo Q, Wang D, Wang Z (2015) Occurrences of pharmaceuticals in drinking water sources of major river watersheds, China. Ecotoxicol Environ Saf 117:132-140 
196. Sun P, Cabrera ML, Huang CH, Pavlostathis SG (2014) Biodegradation of veterinary ionophore antibiotics in broiler litter and soil microcosms. Environ Sci Technol 48(5):2724-2731

197. Suzuki S, Hoa PTP (2012) Distribution of quinolones, sulfonamides, tetracyclines in aquatic environment and antibiotic resistance in Indochina. Front Microbiol 3:67

198. Tahrani L, Van Loco J, Ben Mansour H, Reyns T (2016) Occurrence of antibiotics in pharmaceutical industrial wastewater, wastewater treatment plant and sea waters in Tunisia. J Water Health 14(2):208-213

199. Tang J, Shi T, Wu X, Cao H, Li X, Hua R, Yue Y (2015) The occurrence and distribution of antibiotics in Lake Chaohu, China: seasonal variation, potential source and risk assessment. Chemosphere 122:154-161

200. Tappe W, Hofmann D, Disko U, Koeppchen S, Kummer S, Vereecken H (2015) A novel isolated Terrabacter-like bacterium can mineralize 2-aminopyrimidine, the principal metabolite of microbial sulfadiazine degradation. Biodegradation 26(2):139-150

201. Taşkan B, Hanay Ö, Taşkan E, Erdem M, Hasar H (2016) Hydrogen-based membrane biofilm reactor for tetracycline removal: biodegradation, transformation products, and microbial community. Environ Sci Pollut Res 23(21):21703-21711

202. Tian H, Six DA, Krucker T, Leeds JA, Winograd N (2017) Subcellular chemical imaging of antibiotics in single bacteria using C60-secondary ion mass spectrometry. Anal Chem 89(9):5050-5057

203. Tiecher T, Caner L, Minella JPG, Dos Santos DR (2015) Combining visible-based-color parameters and geochemical tracers to improve sediment source discrimination and apportionment. Sci Total Environ 527:135-149

204. Tiecher T, Minella JPG, Caner L, Evrard O, Zafar M, Capoane V, Dos Santos DR (2017) Quantifying land use contributions to suspended sediment in a large cultivated catchment of Southern Brazil (Guaporé River, Rio Grande do Sul). Agr Ecosyst Environ 237:95-108

205. Topp MS, Gökbuget N, Zugmaier G, Degenhard E, Goebeler M-E, Klinger M, Neumann SA, Horst HA, RaffT, Viardot A, Stelljes $M$, Schaich M, Köhne-Volland R, Brüggemann M, Ottmann OG, Burmeister T, Baeuerle PA, Nagorsen D, Schmidt M, Einsele $H$, Riethmüller G, Kneba M, Hoelzer D, Kufer P, Bargou RC (2012) Long-term follow-up of hematologic relapse-free survival in a phase 2 study of blinatumomab in patients with MRD in B-lineage ALL. Blood 120(26):5185-5187

206. Velpandian T, Halder N, Nath M, Das U, Moksha L, Gowtham L, Batta SP (2018) Un-segregated waste disposal: an alarming threat of antimicrobials in surface and ground water sources in Delhi. Environ Sci Pollut Res 25(29):29518-29528

207. Vincent IM, Ehmann DE, Mills SD, Perros M, Barrett MP (2016) Untargeted metabolomics to ascertain antibiotic modes of action. Antimicrob Agents Chemother 60(4):2281-2291

208. Wammer KH, Korte AR, Lundeen RA, Sundberg JE, McNeill K, Arnold WA (2013) Direct photochemistry of three fluoroquinolone antibacterials: norfloxacin, ofloxacin, and enrofloxacin. Water Res 47(1):439-448

209. Wang H, Wang N, Wang B, Fang H, Fu C, Tang C, Chen Y (2016) Antibiotics detected in urines and adipogenesis in school children. Environ Int 89:204-211

210. Wang S, Wang H (2015) Adsorption behavior of antibiotic in soil environment: a critical review. Front Environ Sci Eng 9(4):565-574

211. Wang W, Yu J, Zou J, Yu X (2016) Mechanism for enhancing biodegradability of antibiotic pharmacy wastewater by in situ generation of $\mathrm{H}_{2} \mathrm{O}_{2}$ and radicals over MnOx/nano-G/2-EAQ/AC cathode. Electrochim Acta 191:426-434
212. Watanabe N, Bergamaschi BA, Loftin KA, Meyer MT, Harter T (2010) Use and environmental occurrence of antibiotics in freestall dairy farms with manured forage fields. Environ Sci Technol 44(17):6591-6600

213. Wegst-Uhrich SR, Navarro DA, Zimmerman L, Aga DS (2014) Assessing antibiotic sorption in soil: a literature review and new case studies on sulfonamides and macrolides. Chem Cent J 8(1):5

214. Wei X, Chen J, Xie Q, Zhang S, Ge L, Qiao X (2013) Distinct photolytic mechanisms and products for different dissociation species of ciprofloxacin. Environ Sci Technol 47(9):4284-4290

215. Weiss SJ, Mansell TJ, Mortazavi P, Knight R, Gill RT (2016) Parallel mapping of antibiotic resistance alleles in E. coli. PLoS ONE 11(1):e0146916

216. Wen X, Wang Y, Zou Y, Ma B, Wu Y (2018) No evidential correlation between veterinary antibiotic degradation ability and resistance genes in microorganisms during the biodegradation of doxycycline. Ecotoxicol Environ Saf 147:759-766

217. Wieczorek K, Osek J (2013) Antimicrobial resistance mechanisms among Campylobacter. BioMed Res Int 20:111

218. Wu C, Spongberg AL, Witter JD (2009) Sorption and biodegradation of selected antibiotics in biosolids. J Environ Sci Health Part A 44(5):454-461

219. Xiao Y, Chen S, Gao Y, Hu W, Hu M, Zhong G (2015) Isolation of a novel beta-cypermethrin degrading strain Bacillus subtilis BSF01 and its biodegradation pathway. Appl Microbiol Biotechnol 99(6):2849-2859

220. Xiong W, Sun Y, Zhang T, Ding X, Li Y, Wang M, Zeng Z (2015) Antibiotics, antibiotic resistance genes, and bacterial community composition in fresh water aquaculture environment in China. Microb Ecol 70(2):425-432

221. Yang SF, Lin CF, Lin AYC, Hong PKA (2011) Sorption and biodegradation of sulfonamide antibiotics by activated sludge: experimental assessment using batch data obtained under aerobic conditions. Water Res 45(11):3389-3397

222. Yang Y, Li B, Zou S, Fang HH, Zhang T (2014) Fate of antibiotic resistance genes in sewage treatment plant revealed by metagenomic approach. Water Res 62:97-106

223. Yao L, Wang Y, Tong L, Li Y, Deng Y, Guo W, Gan Y (2015) Seasonal variation of antibiotics concentration in the aquatic environment: a case study at Jianghan Plain, central China. Sci Total Environ 527:56-64

224. Zampieri M, Zimmermann M, Claassen M, Sauer U (2017) Nontargeted metabolomics reveals the multilevel response to antibiotic perturbations. Cell Rep 19(6):1214-1228

225. Zanotto C, Bissa M, Illiano E, Mezzanotte V, Marazzi F, Turolla A, Radaelli A (2016) Identification of antibiotic-resistant Escherichia coli isolated from a municipal wastewater treatment plant. Chemosphere 164:627-633

226. Zhang CL, Guo XL, Li BY, Wang Y (2012) Biodegradation of ciprofloxacin in soil. J Mol Liq 173:184-186

227. Zhang X, Li R, Jia M, Wang S, Huang Y, Chen C (2015) Degradation of ciprofloxacin in aqueous bismuth oxybromide $(\mathrm{BiOBr})$ suspensions under visible light irradiation: a direct hole oxidation pathway. Chem Eng J 274:290-297

228. Zhang YC, Slomp CP, Broers HP, Passier HF, Van Cappellen $P$ (2009) Denitrification coupled to pyrite oxidation and changes in groundwater quality in a shallow sandy aquifer. Geochim Cosmochim Acta 73(22):6716-6726

229. Zhang Z, Zhao J, Yu C, Dong S, Zhang D, Yu R, Liu Y (2015) Evaluation of aerobic co-composting of penicillin fermentation fungi residue with pig manure on penicillin degradation, microbial population dynamics and composting maturity. Biores Technol 198:403-409

230. Zhou L, Gan N, Zhou Y, Li T, Cao Y, Chen Y (2017) A labelfree and universal platform for antibiotics detection based 
on microchip electrophoresis using aptamer probes. Talanta 167:544-549

231. Zur WPA, Abel S, Gkotzis S, Ocampo P, Engelstädter J, Hinkley T, Cohen T (2015) Classic reaction kinetics can explain complex patterns of antibiotic action. Sci Transl Med 7:287ra73
Publisher's Note Springer Nature remains neutral with regard to jurisdictional claims in published maps and institutional affiliations. 